\title{
静的模型実験によるシートパイル基礎の 水平抵抗メカニズムに関する研究
}

\author{
西岡英俊 1 - 神田政幸 $2 \cdot$ 舘山勝 2 - 喜多直之 ${ }^{3}$ - 平尾淳一 $3 \cdot$ 樋口俊一 4 \\ 1正会員 鉄道総合技術研究所 構造物技術研究部（干185-8536 東京都国分寺市光町2-8-3） \\ E-mail:nishioka@rtri.or.jp \\ 2正会員 鉄道総合技術研究所 構造物技術研究部（同上） \\ 3正会員 株式会社大林組 生産技術本部 都市土木技術部（ $\overline{1} 108-8502$ 東京都港区港南2-15-2） \\ 4正会員 株式会社大林組 技術研究所 構造技術研究部（干205-8558 東京都清瀬市下清戸4-640）
}

\begin{abstract}
筆者らは，仮土留め用鋼矢板を本設利用する鋼矢板併用直接基礎（シートパイル基礎）を提案している. シートパイル基礎は，鋼矢板の地盤拘束効果による高い支持力および而震性が期待できることから，直接 基礎に比べて広い範囲の地盤条件へ適用が可能である。本研究では，シートパイル基礎の地震時の水平抵 抗特性を把握するため, 模型地盤における静的水平交番載荷実験を行った。 その結果, 直接基礎に比べて 降伏震度，降伏剛性が上昇する他，地震時の累積沈下量も低減できることが明らかとなったままた改良効 果の発現メカニズムについて考察を行い，シートパイルの軸力による抵抗成分が主体的であることを明ら かにした。
\end{abstract}

Key Words : footing foundation, sheet pile, seismic resistance, lateral loading test, model test

\section{1. はじめに}

従来，基礎構造物の設計においては，地盤情報の不確 定性や，被災後の復旧の困難さ等を勘案して十分に余裕 を持って設計される場合が多かった。しかしながら，よ り効率的で良質な社会資本整備を進めるため，今後は設 計の余裕度の妥当性についても十分な説明が求められ, 十分な耐震性を確保した上で，より経済性を高めること が求められつつある.

基礎構造物の経済性を高めるには，基礎形式の選定が 非常に重要である．特に鉄道や道路等における中小規模 の高架橋, 橋梁を対象とした場合は, 最も経済性に優れ た基礎形式である直接基礎が採用できるか㧵か，すなわ ち直接基礎で十分な耐震性が確保できるかどうかが，経 済性を大きく左右する.

直接基礎の耐震設計は，従来は偏心およひ傾斜の影響 を考慮した支持力（例えば鉄道構造物)ではMeyerhof $の$ 方法23344)で低減した極限支持力）の照査と滑動抵抗の照 查が主体であった。しかしながら，1995年の兵庫県南部 地震による被害を契機として, 種々の機関で而震設計法 の見直し5がなされた．新しい耐震設計法では，想定す る地震力が大きくなる (L2地震動) 一方, 部材および
地盤の降伏を許容して塑性変形性能を制御寸る設計思想 が導入された．鉄道や道路の橋脚・高架橋の直接基礎の 耐震設計では，慣性力作用位置が比較的高く，回転変形 が主体となるため，L2地震動レベルに対してはフーチ ングの浮き上がりと, 端部地盤の降伏が組み合わさった 非線形挙動となる。 そこで大変位領域までの水平載荷実 験に基づき, フーチング底面反力による抵抗モーメント を非線形回転バネでモデル化する設計手法が提案され9 現在の鉄道構造物の耐震設計》に適用されている.

また, 直接基礎の地震時の問題として, 摇すり込み沈 下による残留沈下の問題がある. 例えば2004年の新潟県 中越地震では，沖積段丘堆積層上の直接基礎新幹線橋脚

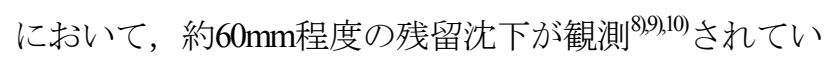
る. 近年の鉄道構造物においては，不同変位に対寸る調 整可能幅が小さいスラブ軌道が主体であり, 残留沈下量 の大小は地震後の復旧性に大きな影響を及ぼす。よって, 残留沈下量の低減および定量的な評価法の確立は直接基 礎の耐震設計上の課題の一つとなっており, 繰返し荷重 を作用させる模型実験(11),12)や， $M-V-H$ (モーメント-鉛直 力-水平力）空間上の降伏曲面 ${ }^{13) 14}$ およひ塑性ポテンシャ ルから沈下量を含めた塑性変形量を評価する手法 ${ }^{15}$ の研 究が進められている. 


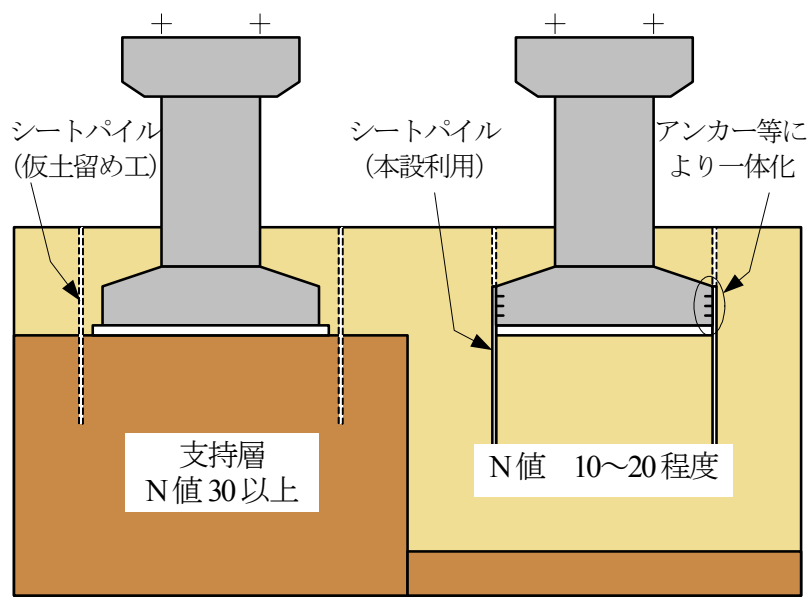

a）直接基礎

b）シートパイル基礎

図-1 直接基礎とシートパイル基礎の概要と適用地盤

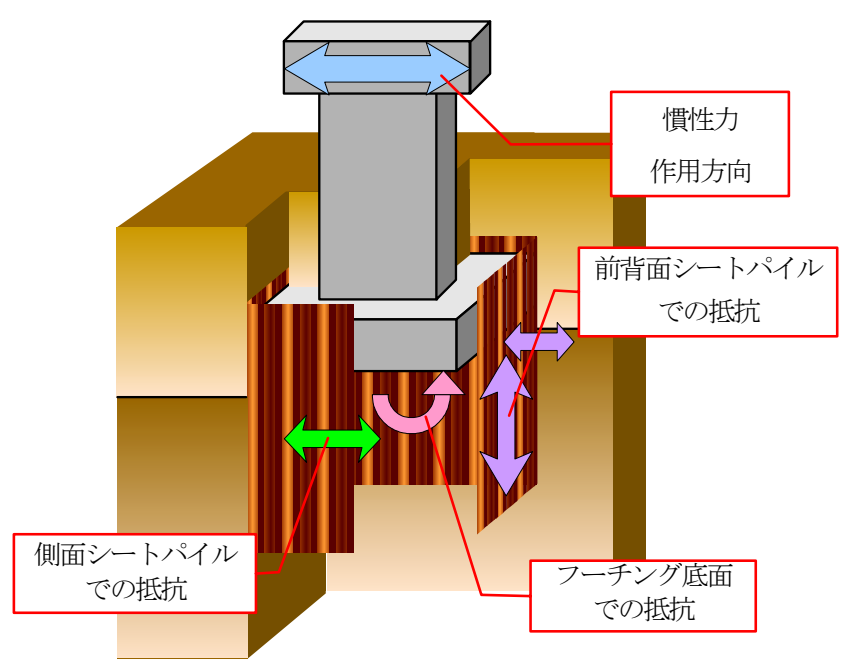

図-2 シートパイル基礎の地震時水平抵抗メカニズム

実務設計上は，このような直接基礎の地震時の沈下を 抑制するため, 直接基礎を適用する支持地盤の条件を制 限しており，例えば鉄道構造物では砂地盤の場合でN值 30 以上かつ常時の底面反力度が $400 \mathrm{kN} / \mathrm{m}^{2}$ 以内之非常に厳 しく規定1)されている.この支持地盤条件を満足しない 地盤であっても，フーチングを大きく設計して直接基礎 を適用した事例15,16ももるが，入念な地盤調查と施工管 理が必要とされる，そのため，ほとんどの場合は杭基礎 形式が採用され，直接基礎形式よりもコスト増となって いるのが実状である.

以上のような背景から，基礎構造物の経済性を高める 一つの方法として, 直接基礎と杭基礎の適用地盤の中間 的な性状を有する地盤において，フーチング底面の地盤 反力を有効に活用した基礎形式を開発し，直接基礎の適 用範囲を広げることが有効と考えられる．このような直 接基礎を改良した基礎形式として，パイルド・ラフト基 礎が主に建築分野で用いられている ${ }^{18)}$. この基礎は，不 完全支持杭の支持力とフーチング底面での地盤反力の両 者を組み合わせるものであり，工場基礎など，杭長に比 べて比較的平面規模の大きい構造物での適用が多い.
一方，筆者らは，主に鉄道や道路等の橋脚や高架橋な ぞの比較的平面規模が小さい構造物を対象として, 直接 基礎の適用範囲を拡大したシートパイル基礎（鋼矢板併 用型直接基礎）を提案している ${ }^{19}$. 直接基礎のフーチン グの掘削には図-1 a）に示寸ように仮土留め工が必要で あるが，シートパイル基礎は図-1 b) に示寸ように仮土 留め用シートパイル（鋼矢板）をフーチングと一体化し て本体利用寸る基礎形式である. シートパイルの根入れ 長さ（フーチング下面から先端までの長さ）はフーチン グ幅の $0.5 \sim 1.0$ 倍程度（ただし土留め工としての必要長 さ以上）とし，シートパイル自体は地震時にも塑性化し ないように設計する（必要な板厚を確保する）こと，フ 一チングとシートパイルはアンカー鉄筋等により剛結20) することを前提としている. フーチングの型枠工の省略 や掘削面積の削減, 工期短縮効果の他, 従来の直接基礎 で散見されるシートパイル引抜き時に支持地盤を緩めて 沈下，傾斜を生じるトラブルの贃念がないなど，経済性， 施工性の観点からも合理的な基礎形式である.

シートパイル基礎の鉛直支持力特性については，模型 基礎の鉛直載荷実験により，シートパイルによるフーチ ング底面地盤の拘束効果とシートパイル自体の鉛直支持 力の上昇効果が組み合わされ, 直接基礎とシートパイル の個々の支持力の和を上回る鉛直支持力が発揮されるこ とを確認している21). 一方, シートパイル基礎の地震時 の水平抵抗特性についても, 直接基礎を上回る水平抵抗 力だけではなく, 摇すり込み沈下量の抑制効果も期待さ れる. シートパイル基礎の水平抵抗メカニズムは図-2に 示寸ように主にフーチング底面，前背面（慣性力作用方 向に対して直交する面）シートパイル，側面（慣性力作 用方向に対して平行な面）シートパイルに分離して考え ることができる．フーチング底面では主に鉛直抵抗およ び回転抵抗が期待される．前背面シートパイルでは鉛直， 水平, 曲げ抵抗が期待され, 側面シートパイルでは主に 水平方向へのせん断抵抗が期待される.

このようにシートパイル基礎は高い耐震性が期待さ れるものの, これまで水平抵抗メカニズムに関する研究 は実施されていなかったのが実状である. そこで本研究 では，特に基礎の変形との干渉が大きいと考えられるフ 一チング底面と前背面シートパイルでの地盤抵抗に着目 した重力場の2次元平面ひずみ条件での模型水平交番載 荷実験を実施し, 直接基礎に対する定性的な改良効果を 整理するとともに, 画像解析システムによる地盤変位観 測結果や底面反力分布形状等からシートパイル基礎の地 震時の抵抗メカニズムについて考察する.

なお，本研究ではシートパイルとフーチングを剛結 した条件を対象としているが，結合度の影響（強固に結 合しない場合）については別報2)を参照されたい。 


\section{2. 実験の概要}

本研究では，シートパイル基礎を橋脚基礎として適用 した場合の地震時水平力に対する抵抗特性について検討 するため，死荷重に相当する鉛直荷重を作用させながら， 橋脚の桁重心に相当する位置で地震時慣性力に相当する 水平荷重を正負交番に載荷する水平交番載荷実験を実施 した．実験の概要を以下に示す。

\section{（1） 模型の概要}

実構造物として鉄道単線橋脚基礎を想定し，図-3に示 すようなフーチング幅 $B=4.8 \mathrm{~m}$ の直接基礎およびシート パイル基礎に対して，約1/50スケールとなるフーチング 幅 $B=100 \mathrm{~mm}$ の模型とした.

模型地盤については，幅 $2000 \mathrm{~mm} ，$ 奥行き $605 \mathrm{~mm}$ の 槽内に乾燥豊浦砂を用いて空中落下法で深さ $580 \mathrm{~mm}$ と なるように作製した．地盤強度の違いによる改良効果一 の影響を検討するため, 密な地盤として相対密度 $D_{r}=$ 90\%（乾燥密度1.61 $\mathrm{g} / \mathrm{cm}^{3}$ ，単位体積重量 $\gamma=15.8 \mathrm{kN} / \mathrm{m}^{3}$ ) と，緩い地盤として相対密度 $D_{r}=60 \%$ （乾燥密度 1.50 $\left.\mathrm{g} / \mathrm{cm}^{3}, \gamma=1.47 \mathrm{kN} / \mathrm{m}^{3}\right)$ の2種類を用いた。地盤変位の観 察を行うため，土槽の前背面は透明アクリル板（厚さ50 $\mathrm{mm}$ と $30 \mathrm{~mm}$ 枚重水）とし，鋼製フレームで2次元平 面ひずみ条件とするための剛性を確保した．アクリル板 での摩擦低減を図るため，その内面にグリスを塗布した 上にメンブレンを貼り付けてから模型地盤を作製した. 地盤変位はあらかじめメンブレンに標点を記しておき， 前面からデジタルカメラで順次撮影して, 画像解析シス

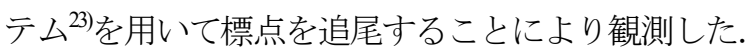

基礎模型はアルミ製フーチングによる直接基礎模型と, それにリン青銅製シートパイル模型を剛結（ネジ止め） したシートパイル基礎模型（図-4）とした。フーチング

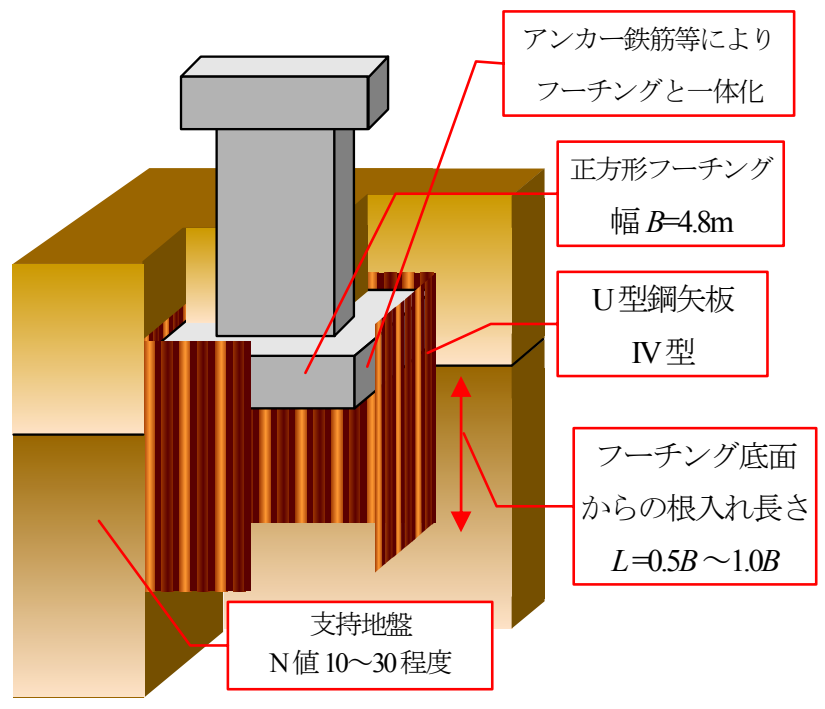

図-3 想定する実構造物形状
の奥行きは土槽奥行きとほぼ同等の $600 \mathrm{~mm}$ とた. フ ーチング底面中央の奥行き $200 \mathrm{~mm}$ 区間には図-4中に示す ように2方向門型ロードセル ${ }^{24}$ を5分割して配置し，底面 の鉛直応力度およびせん断応力度を計測した。

また，直接基礎の根入れ効果を検討寸るケース（後述 のcase-HF3L）では，根入れ深さ分だけ低い位置まで地 盤を作製した段階でアルミブロック製の根入れ部を設置 してから，残りの周辺地盤を所定高さまで作製した。 そ の後, 一体として挙動するように根入れ部とフーチング 部を固定した.

\section{（2）模型シートパイル}

模型シートパイルは，その剛性の影響を検討するた め，実物同様の凹凸形状（図-5）となるようにプレス加 工した凹凸模型と，板厚は同一で凹凸加工を施さない平 板模型の 2 種類を用いた．なお，板厚を同一として，凹 凸加工の有無により剛性の違いを模擬するのは，先端の 鉛直抵抗を両模型で同程度とするためである．また，シ 一トパイルの根入れ長さ $L$ にいては，図-3の想定実構 造物形状に応じたフーチング幅 $B$ と同一の $100 \mathrm{~mm}$ と $1 / 2$ の0 $\mathrm{mm} の 2$ 種類を用いた.

実物のIV型鋼矢板と各模型シートパイルの諸元を表-1 に示す．なお，模型シートパイルの各数值は，奥行き $100 \mathrm{~mm}$ 分（フーチング幅 $B$ 相当）での值である. 板厚 $t$ は，フーチング幅 $B$ との比 $t / B$ が想定する実構造物と同 程度となるよう $t=0.2 \mathrm{~mm}$ とした。

凹凸模型の断面加工形状（図-5）は，実物のIV型鋼矢

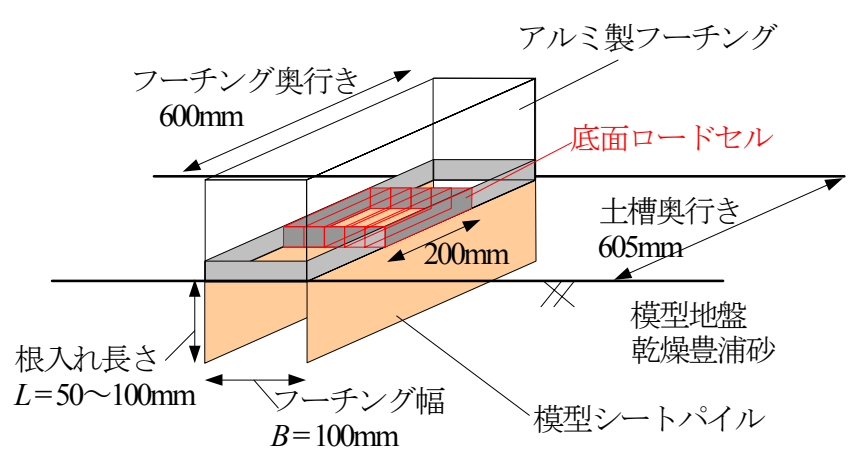

図-4 シートパイル基礎模型形状

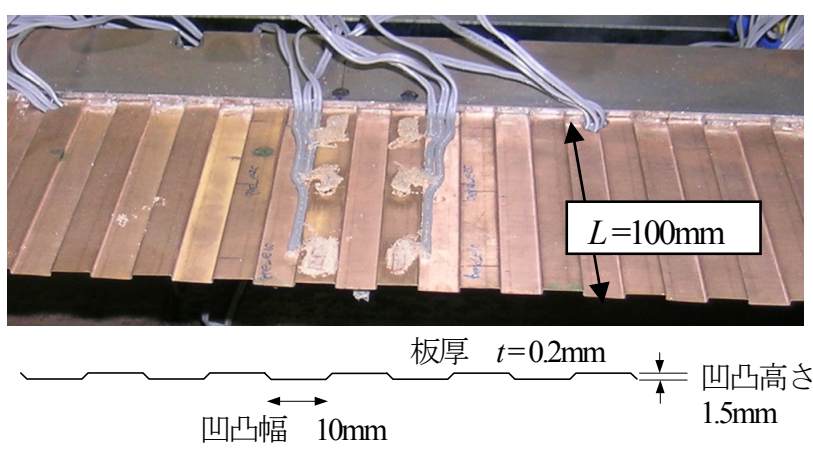

図-5＼cjkstart模型シートパイル 凹凸模型（長さ $L=100 \mathrm{~mm}$ ) 
表-1＼cjkstart模型シートパイルの断面諸元

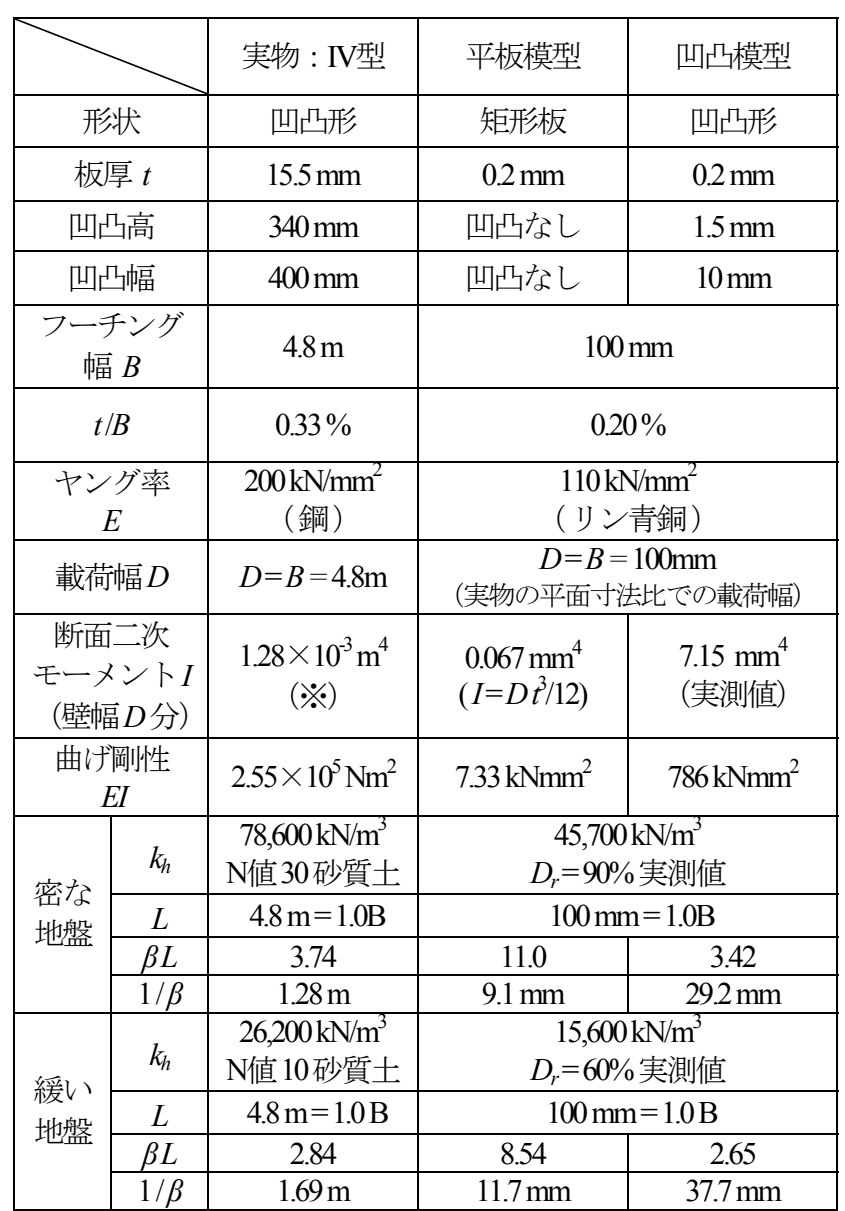

※ 両側1mmの腐食代を考慮した值 ${ }^{24)}$ 継手効率 $80 \%{ }^{26,27)}$ で低減

板の剛性と地盤剛性の相対比を一致させるため，相似則 として，式(1)に示す杭の特性值 $\beta$ とシートパイルの根入 れ長さ $L$ の積 $\beta L$ がほぼ等しくなるように決定した。

$$
\beta L=\sqrt[4]{k_{h} D / 4 E I} \cdot L
$$

ここで， $\beta$ : 杭の特性值 $(1 / \mathrm{m}) ， k_{h}$ : 地盤反力係数 $\left(\mathrm{kN} / \mathrm{m}^{3}\right) ， D$ : 載荷幅 $(\mathrm{m}), E I$ : 曲げ岡性 $\left(\mathrm{kNm}^{2}\right)$, $L:$ シートパイルの根入れ長さ $(\mathrm{m})$ である.

実物に対する諸元のうち, 断面 2 次モーメント $I$ は, 凹凸に組み合わせた幅 $D$ の壁体としての值から片側 1 $\mathrm{mm}$ づつの腐食代を考慮して低減した值 ${ }^{25}$ を，さらに継 手効率 $80 \%{ }^{26,27)}$ で低減した值とした. 地盤反力係数 $k_{h}$ に ついては，想定する $\mathrm{N}$ 值から，以下に示す鉄道設計標 準 ${ }^{1)}$ の砂質地盤上の直接基礎の設計水平地盤反力係数算 定式(2)により算出した.

$$
k_{h}=1.7 \alpha E_{0} D^{-3 / 4}, \quad E_{0}=2500 \mathrm{~N}
$$

ここで， $E_{0}$ : 地盤の変形係数 $\left(\mathrm{kN} / \mathrm{m}^{2}\right) ， \alpha$ : 補正係数 （標準貫入試験の場合には $\alpha=2 ） ， N$ ：N 值である． $\mathrm{N}$ 值は密な地盤は鉄道設計標準 ${ }^{1)}$ における良質な支持層の 条件となる $N=30$ とし, 緩い地盤は想定するシートパイ
ル基礎の適用下限值として $N=10$ とした.

一方，模型シートパイルの $\beta L$ の算出にあたっては， 載荷幅 $D$ を模型フーチングの奥行き $(600 \mathrm{~mm})$ ではな く，実物での平面寸法比に合わせたフーチング幅 $B=$ $100 \mathrm{~mm}$ として求めた. 地盤反力係数 $k_{h}$ については, 別 途実施した直接基礎模型の鉛直載荷実験 ${ }^{21)}$ における鉛直 方向地盤反力係数の実測值を用いた.

模型シートパイルにはひずみゲージ（東京測器研究所 製 FLA-5-17 : 一般用単軸ゲージ，ステンレス鋼・銅合金 用）を貼付して曲げひずみを計測し，曲率および曲げモ 一メントを求めた。ひずみゲージ貼付深度は頭部（基部 から10 mm）および地中部（基部から50 mm，シートパ イル根入れ長さ $L=100 \mathrm{~mm} の$ 模型のみ）とした. なお， 軸ひずみの計測も試みたが，板状ということもあり有意 なデータが取得できなかった。 また，全実験ケースにお いて実験終了後に模型シートパイルを観察したところ, 塑性変形は生じておらず，いずれも弾性範囲内で挙動し たと考えられる.

\section{（3）載荷装置}

基礎構造物に鉛直荷重と水平荷重および回転モーメ ントの組み合わせ荷重を作用させる模型実験では，コン クリート部材での 2 軸試験 ${ }^{28)}$ 等に比べて変位量が大きく なるため, ジャッキ荷重, 特に鉛直荷重を作用させ続け るための工夫が必要となる，最も簡易かつ確実に鉛直荷 重を作用させる方法は，鉄塊等の錘の自重による方法の であるが，橋梁の桁相当の死荷重を作用させるには非常 に大きな錘が必要となるため，実験可能な鈆直荷重レべ ルが比較的小さくなってしまうことや，基礎の傾斜によ り偏心モーメントが生じた場合 $(P-\delta$ 効果 $)$ の制御が 難しくなることなどの問題がある. 一方，鉛直荷重をジ ヤッキにより載荷させる場合には，基礎の大きな変形に ジャッキの載荷軸を追随させる特殊な載荷装置が必要と なる．鉛直荷重をジャッキで載荷した実験事例としては, 滑動装置に固定した水平ジャッキごと鈆直ジャッキで載

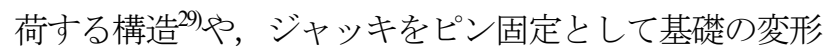
に応じてジャッキが回転する構造30), 滑動装置上にピン 固定したジャッキを組み合わせた構造31),32)などがあり， それぞれ実験対象としている基礎の変形の特徵に応じた 工夫がなされている.

本研究においては，水平力の載荷高さが比較的高く， 回転モーメントが主体となること，基礎の累積沈下が生 じること等の条件を考慮し, 図一6に示すような載荷装置 を新たに考案・製作して水平交番載荷実験を行った．以 下にその構造を説明する.

鈆直ジャッキは荷重制御とするため, 空圧制御のベ ロフラムシリンダーを使用した. フーチング側のヒンジ 
部（くさび構造）を滑動装置（リニアガイド）の上に配 置して，フーチングの変位（水平変位，沈下，回転）に 追随できる構造とした. 水平ジャッキは変位制御とする

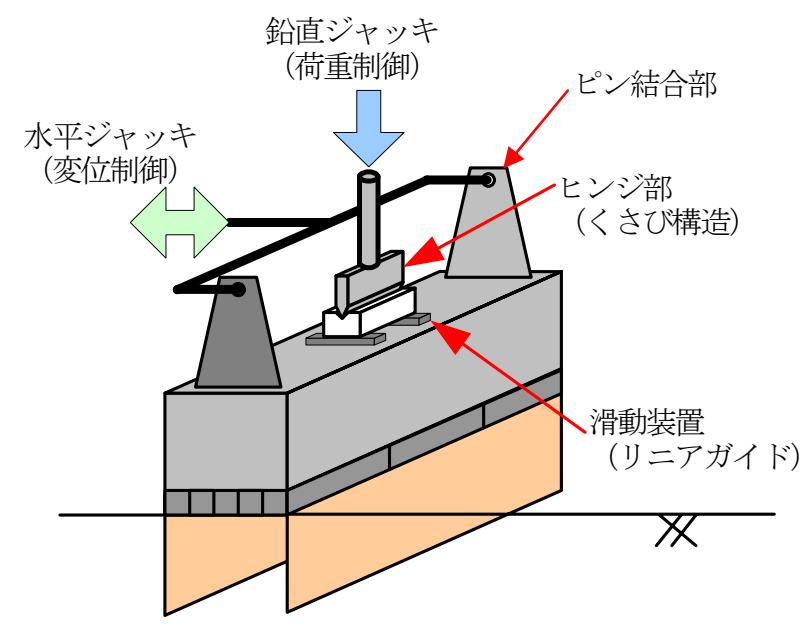

a）装置の概要

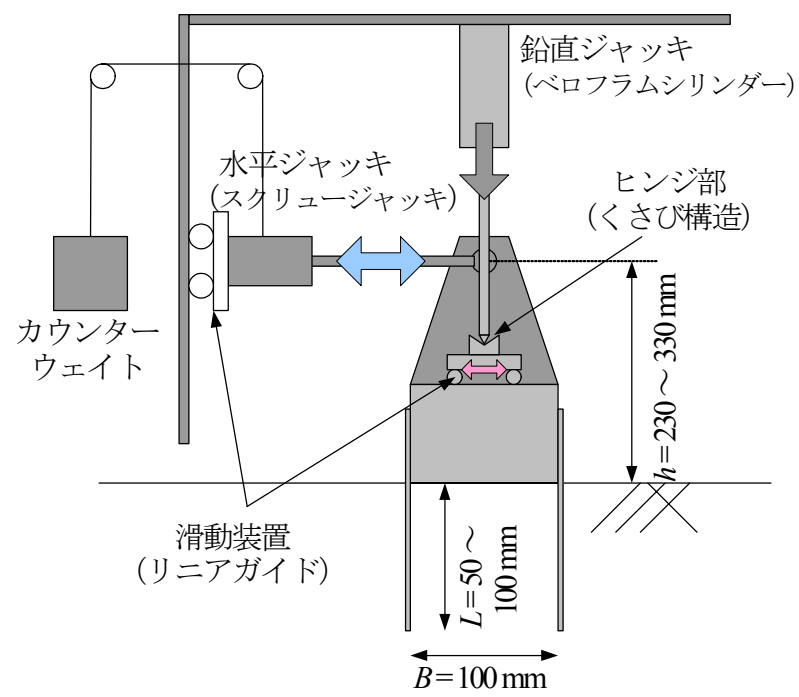

b) 側面図

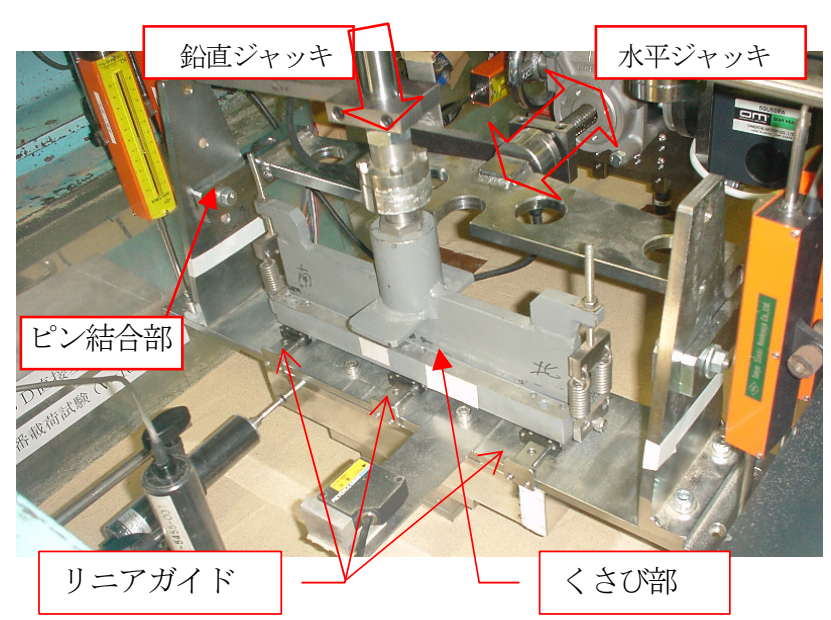

c) 載荷装置 写真

図-6 水平載荷実験装置
ため, スクリュージャッキを使用し，水平ジャッキ自体 を鉛直リニアガイドに固定して鉛直変位に追随できる構 造とした. その際, 水平ジャッキはカウンターウェイト によりその自重が基礎模型に作用しないようにした. 水 平ジャッキの先端は，フーチング底面から $230 \mathrm{~mm}$ よ び $330 \mathrm{~mm}$ (フーチング幅の 2.3〜3.3 倍）の高さにピン結 合した。これは実構造物において高さ 10〜 $16 \mathrm{~m}$ 程度の単 線鉄道橋脚の桁重心位置として想定したものである.

なお，このような載荷装置の構造上，フーチングの変 形が生じると鉛直荷重の作用軸線とフーチング中心がず れるため, 鉿直荷重による偏心モーメントが発生する.

これは実際の構造物の自重作用位置が偏心した際に作用 する偏心モーメント（いわゆる $P-\delta$ 効果） とは逆方向 の作用となるが，いずれの方向の偏心であってもその影 響を適切に補正すれば基礎の抵抗特性としての評価には 支障は無いと考えられる. そこで本研究では，フーチン グ底面中心に作用するモーメントおよび水平力について 次式により補正を行った（図-7）.

$$
\begin{aligned}
& M^{\prime}=P \times h-V \times u \\
& P^{\prime}=M^{\prime} / h \\
& u=\delta-h \tan \theta
\end{aligned}
$$

ここで, $M^{\prime}$ : 補正載荷モーメント, $P^{\prime}$ : 補正水平荷重, $P$ : 水平ジャッキ荷重, $V:$ 鉛直ジャッキ荷重, $h:$ 水平 力載荷高さ, $u$ : フーチング水平変位, $\delta:$ 天端水平変位, $\theta:$ フーチング回転角である.

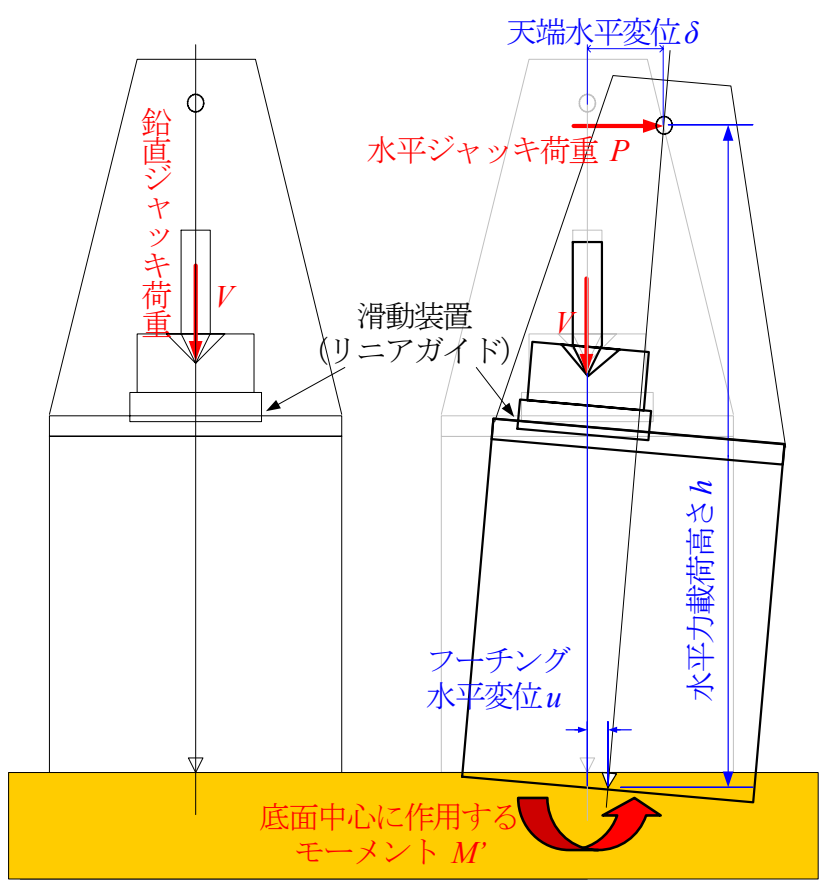

a) 変形前

b) 変形後

図-7 載荷モーメントおよび載荷水平力の補正 


\section{（4）模型の設置および固定方法}

シートパイル基礎は，実施工においては仮土留めとし て用いたシートパイルを外型枠に兼用してフーチングコ ンクリートを打設することとなるため，鉛直荷重に対し てシートパイルの支持力のみで負担するのではなくフー チング底面での荷重負担も十分期待できると考えられる. そこで水平交番載荷試験の初期状態においてもシートパ イル基礎のフーチング底面にも鉛直荷重がある程度作用

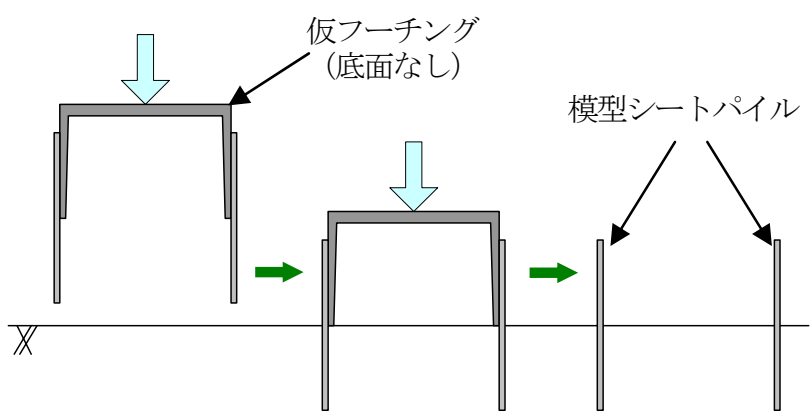

a）手順<1> 模型シートパイルの貫入

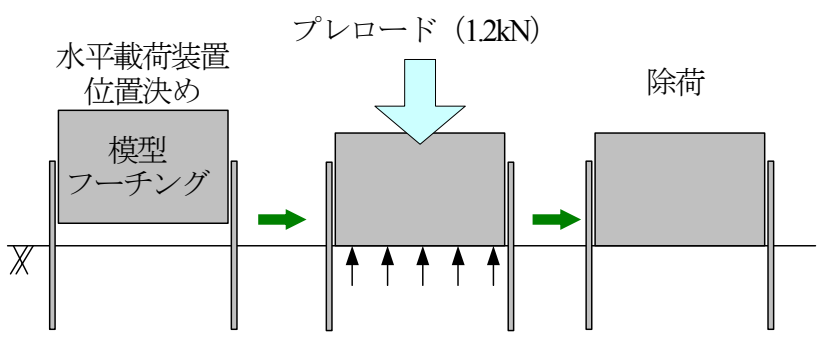

b）手順<2> 底面プレロード

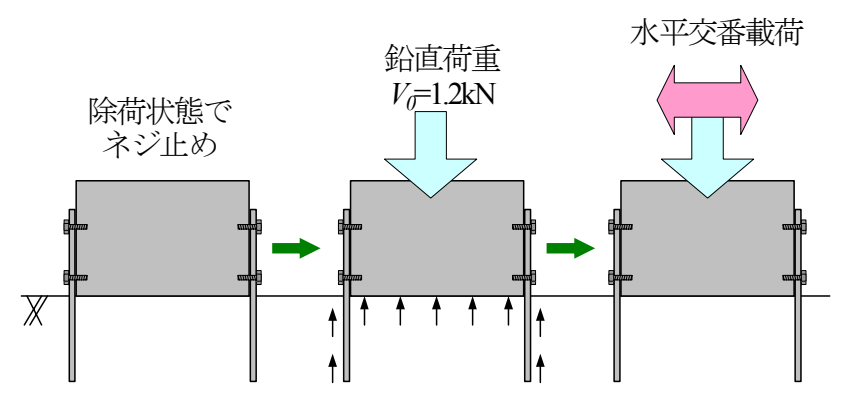

c）手順<3> 模型シートパイルの固定から載荷実験

図-8 模型設置から載荷実験の手順

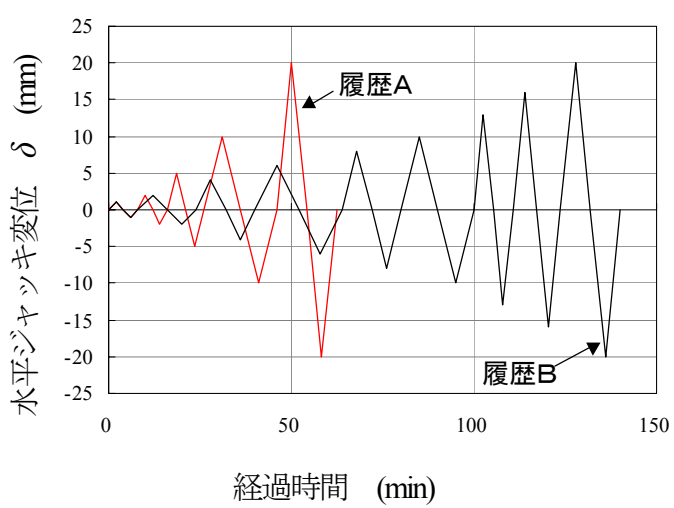

図-9 正負交番載荷 作用変位履歴
した状態が模擬できるような，フーチングとシートパイ ルの固定方法とすることが重要であり，本実験では図-8 および以下に示す手順で模型を設置，固定し，載荷実験 を行った.

手順<1>（図-8 a）） まず所定の高さまで地盤を作製 した後に，模型シートパイルを底面のない仮フーチング に固定して鉛直載荷試験 ${ }^{21)}$ 用のスクリュージャッキによ り貫入した. 全長を貫入した後, 模型シートパイルから 仮フーチングを取り外した.

手順<2>（図-8 b) ）次に載荷装置を水平交番載荷用 装置（図-6）に取り替え，模型フーチングを所定位置付 近に設置した。ここで模型地盤表面の緩みの影響を除去 するため，フーチングとシートパイルを結合する前に一 旦フーチングのみで底面プレロードを行った，プレロー ドの荷重は後述する目標鉛直荷重 $V_{0}$ と同程度の $1.2 \mathrm{kN}$ 程 度とした.

手順<3>（図-8 c)） その後，模型フーチングが浮か ない程度の最小限の荷重（0.1 kN 程度）まで除荷した状 態で，模型シートパイルを模型フーチング側面にネジで 固定した．そして再度鈆直荷重を増加させて所定の目標 鈶直荷重 $V_{0}$ に設定した後に，水平交番載荷を行った.

上記の模型設置および固定方法を採用した結果，水平 交番載荷試験中のフーチング底面の鈆直反力は，概ね鈆 直ジャッキ荷重 $V$ の $40 ６ 0 \%$ 程度（後述の図-22参照） となり，フーチング底面とシートパイルの両方に反力が 発揮された状態を模擬することができた.

\section{（5） 目標鉛直荷重および水平変位履歴}

水平交番載荷は，所定の目標鉛直荷重 $V_{0}$ を設定した 後に，水平ジャッキにより正負交番でピーク変位を漸増 する変位制御により行った．載荷する水平変位履歴は, 杭の水平載荷試験方法・同解説の交番多サイクル方式 ${ }^{33)}$ を参考に，図-9に示す2種類とした。なお，本論文では， 天端水平変位 $\delta$ が正の方向を紙面右側方向として，シー トパイルや地盤の左右方向を表すこととする.

表-2 実験ケース

\begin{tabular}{|c|c|c|c|c|c|c|c|}
\hline \multirow{2}{*}{ case } & \multirow{2}{*}{$\begin{array}{l}\text { 基礎 } \\
\text { 種別 }\end{array}$} & \multicolumn{2}{|c|}{ 相対密度 $D_{r}$} & \multirow{2}{*}{$\begin{array}{c}\text { 根入長 } \\
D_{f}, \quad L\end{array}$} & \multirow{2}{*}{$\begin{array}{l}\text { 断面 } \\
\text { 形状 }\end{array}$} & \multirow{2}{*}{$\begin{array}{c}\text { 載荷高 } \\
\quad h\end{array}$} & \multirow{2}{*}{$\begin{array}{l}\text { 載荷 } \\
\text { 履歴 }\end{array}$} \\
\hline & & 目標 & 実測 & & & & \\
\hline HF1D & \multirow{4}{*}{$\begin{array}{l}\text { 直接 } \\
\text { 基礎 }\end{array}$} & $90 \%$ & $87.4 \%$ & $0 \mathrm{~mm}$ & & \multirow{3}{*}{$230 \mathrm{~mm}$} & A \\
\hline HF2L & & \multirow{3}{*}{$60 \%$} & $64.4 \%$ & $0 \mathrm{~mm}$ & & & \multirow{8}{*}{ B } \\
\hline HF3L & & & $60.4 \%$ & $50 \mathrm{~mm}$ & & & \\
\hline HF4L & & & $60.4 \%$ & $0 \mathrm{~mm}$ & $\sqrt{2}$ & $330 \mathrm{~mm}$ & \\
\hline HS1D & \multirow{5}{*}{$\begin{array}{c}\text { シート } \\
\text { パイル } \\
\text { 基礎 }\end{array}$} & $90 \%$ & $86.2 \%$ & $100 \mathrm{~mm}$ & 西枮 & \multirow{4}{*}{$230 \mathrm{~mm}$} & \\
\hline HS2L & & \multirow{4}{*}{$60 \%$} & $64.4 \%$ & $100 \mathrm{~mm}$ & 平双 & & \\
\hline HS3L & & & $60.1 \%$ & $100 \mathrm{~mm}$ & & & \\
\hline HS4L & & & $60.1 \%$ & $50 \mathrm{~mm}$ & 凹凸 & & \\
\hline HS5L & & & $60.4 \%$ & $50 \mathrm{~mm}$ & & $330 \mathrm{~mm}$ & \\
\hline
\end{tabular}

$\mathrm{F}$ : 直接基礎, $\mathrm{S}:$ シートパイル基礎

$\mathrm{D}$ : 密地盤 $\left(D_{r}=90 \%\right) ， \mathrm{~L}$ : 緩地盤 $\left(D_{r}=60 \%\right)$ 
目標鉛直荷重 $V_{0}$ は実際の直接基礎構造物の死荷重レ ベルを模擬することとした. 現行の鉄道設計標準 ${ }^{11,7)}$ り而震設計された直接基礎橋脚では，死荷重と極限支持 力の比がおよそ 5 ～10\%程度となる事例が多い（例えば 文献 ${ }^{34)}$ ）。そこで本実験では，別途実施した相対密度 $D_{r}$ $=90 \%$ での直接基礎の鈆直載荷実験 ${ }^{21)}$ から得られた極限 支持力度の $10 \%$ 程度となる $1.2 \mathrm{kN}$ を目標鉛直荷重 $V_{0}$ とし て制御した。ただし，鉛直ジャッキ(ベロフラムシリン ダー）の空気圧は，圧力計を目視しながら手動で圧力弁 を調整したため，載荷中にロードセルで計測した鈆直ジ ヤッキ荷重 $V$ はおよそ $1.1 \sim 1.5 \mathrm{kN}$ 程度の範囲で変動した.

\section{（6）実験ケースと計測項目}

水平交番載荷実験は，地盤密度，根入れ深さ，シート パイル岡性，水平力作用位置等をパラメーターとする 表-2に示す9ケースを実施した.

計測項目は, 鉛直ジャッキの荷重 $V$ と変位量 $s$ （沈下 量）, 水平ジャッキの荷重 $P$ と変位量 $\delta$ （天端水平変位 量）のほか, フーチングの回転角 $\theta$, 底面反力度, 模型 シートパイルの曲げひずみとした。 なお，各変位量は目

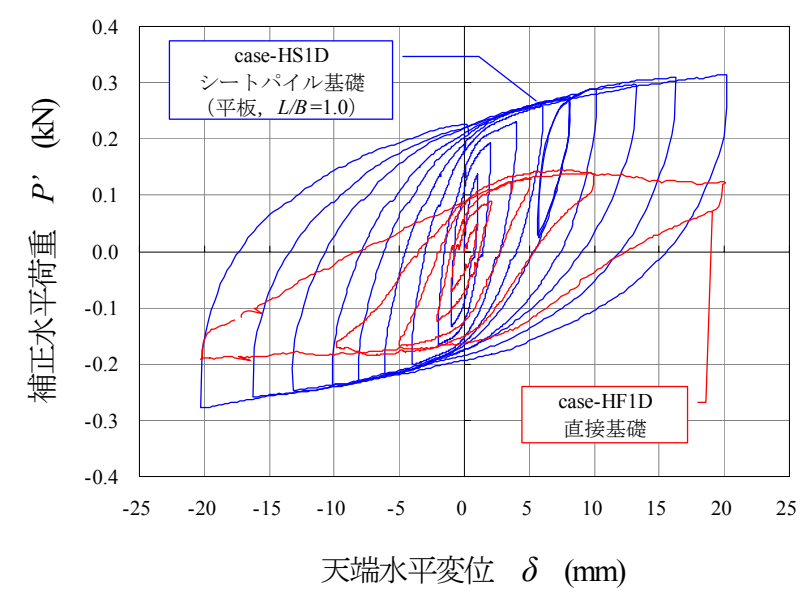

a) case-HF1D, HS1D $\left(D_{r}=90 \%\right)$

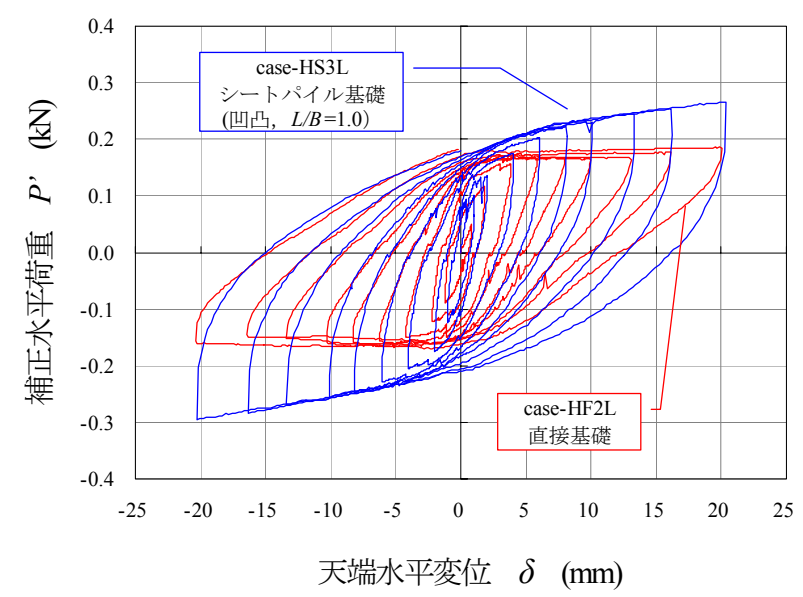

b) case-HF2L, HS3L $\left(D_{r}=60 \%\right)$

図-10 水平荷重 $P$ ～天端水平変位 $\delta$ 関係
標鈆直荷重設定完了時をゼロとし，底面反力度はフーチ ング設置前の無負荷状態をゼロとした.

\section{3. 水平交番載荷実験結果}

\section{（1）荷重変位関係 35$), 36,37)$}

図-10に直接基礎とシートパイル基礎の補正水平荷重 $P^{\prime} \sim$ 天端水平変位 $\delta$ 関係の履歴曲線の例を示す. 直接 基礎は $\delta=3 \sim 5 \mathrm{~mm}$ で岡性が大きく低下し, その後の2 次勾配がほとんどなく一定荷重を保持している. 一方, シートパイル基礎は $\delta=2 \mathrm{~mm}$ 程度で剛性低下しているが, その後の 2 次勾配があり, 変位が進むにつれて水平抵抗 力は増加しつづけている. なお, 本研究ではこのように 荷重変位関係上で岡性低下が生じた時点を，基礎の「降 伏」と定義することとする．図-10 から降伏荷重につい て比較すると, シートパイル基礎は直接基礎を上回って いる．また，図-10 の履歴曲線の除荷勾配をみると，シ 一トパイル基礎は同一サイクル時の直接基礎の履歴ルー プと同等かそれよりも大きくなっている. 特に $D_{r}=$

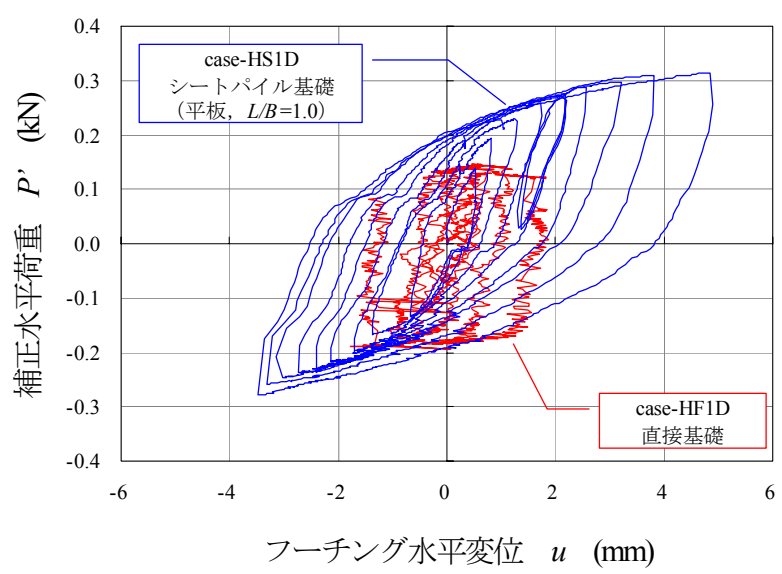

a) case-HF1D, HS1D $\left(D_{r}=90 \%\right)$

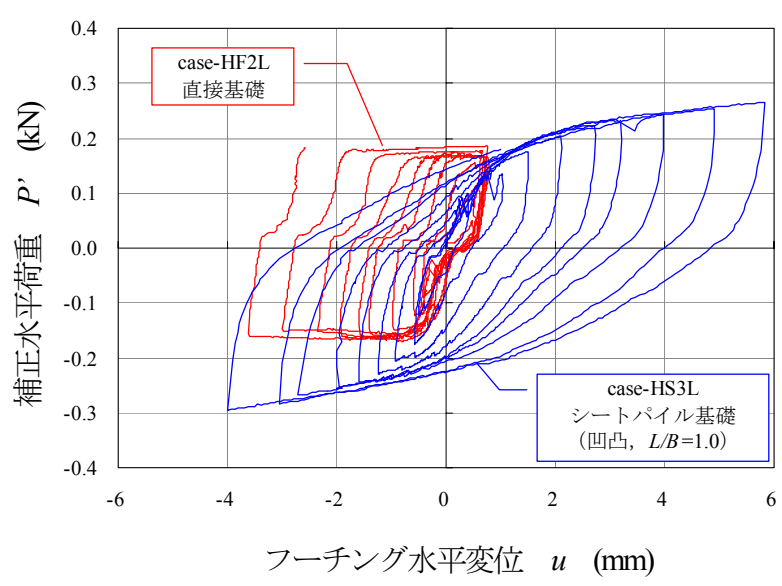

b) case-HF2L, HS3L $\left(D_{r}=60 \%\right)$

図-11 水平荷重 $P$-フーチング水平変位 $u$ 関係 
$90 \%$ の場合（図-10 a)）ではその差が顕著に現れており, シートパイル基礎の方が高い減衰特性・エネルギ一吸収 特性を有していることがわかる.

図-11 には，補正水平荷重 $P$ ’フーチング水平変位 $u$ 関係の履歴曲線を示す. シートパイル基礎の方がフーチ ング水平変位が大きく, 逆に直接基礎はフーチング水平 変位は小さく回転変形が主体となっていることがわかる. また， $D_{r}=60 \%$ の直接基礎（図-11 b)）では載荷が進む につれてフーチングの水平変位が負側に累積しており, 滑動が生じていることがわかる.シートパイル基礎では 正負で差は生じるものの，累積的な変形は生じていない．

\section{（2）各種条件による荷重変位関係の定性的傾向}

荷重変位関係の定性的傾向を把握するため, 正負交番 載荷における各載荷サイクルの折り返し点を結んだ骨格 曲線で各ケースを比較する，骨格曲線は正負両側に得ら れるが，ここでは両側を平均して示す．図-12 が補正水 平荷重 $P^{\prime} \sim$ 天端水平変位 $\delta$ 関係, 図-13 が補正載荷モ一 メント $M^{\prime} \sim$ 回転角 $\theta$ 関係の骨格曲線である. なお，こ れ以降，各ケースの比較を行う上では，「基本ケースと なる根入れのない直接基礎に対する改良効果」に着目す ることとし，特に断わりのない限り「〜の改良効果」と 比較対象を省略して表現する。

\section{a) 根入れ長さの影響}

図-12 a)では，根入れ長さの異なるケースでの水平抵 抗を比較している. 根入れ深さ $D_{f}=50 \mathrm{~mm}$ の直接基礎 (case-HF3L) と同じシートパイル根入れ長さ $L=50 \mathrm{~mm}$ のシートパイル基礎（case-HS4L）がほぼ同等の改良効 果であり，シートパイル根入れ長さは，直接基礎の根入 れ深さと同程度の影響があることがわかる．また，根入 れ長さが長い $L=100 \mathrm{~mm}$ のシートパイル基礎（caseHS3L）はさらに高い改良効果を発揮している.

\section{b） シートパイルの剛性の影響}

図-12 b)では，シートパイルの曲げ岡性 EI の異なる ケースを比較している. 曲げ剛性の高い凹凸模型（caseHS3L）の方が，平板模型（case-HS2L）よりも初期岡性 改良効果が大きい. しかしながら，載荷変位が大きくな るとその差は小さくなり，最終サイクル時（ $\delta=20$ $\mathrm{mm}$ ) ではほぼ同等となっており, 終局状態でのシート パイル岡性の影響はシートパイル根入れ長さに比べて小 さいといえる.

\section{c）地盤密度の影響}

図-12 b)では，地盤密度の異なるケースも比較してい る. 直接基礎同士では，地盤密度の違いはほとんどない． これはフーチングの浮き上がりが非線形化の主要因とな ったためと考えられる.

一方，シートパイル基礎では， $D_{r}=90 \%$ のケース
(case-HS1D) の方が， $D_{r}=60 \%$ でシートパイル剛性， 根入れ長さが同一のケース (case-HS2L) よりも改良効 果が大きくなっており，密な地盤ほど，シートパイル基 礎の改良効果は大きくなる傾向にある.

\section{d）載荷高さの影響}

図-13 では，載荷高さの異なるケースについて，モー メント $M$ ' と回転角 $\theta$ の関係で整理して比較している.

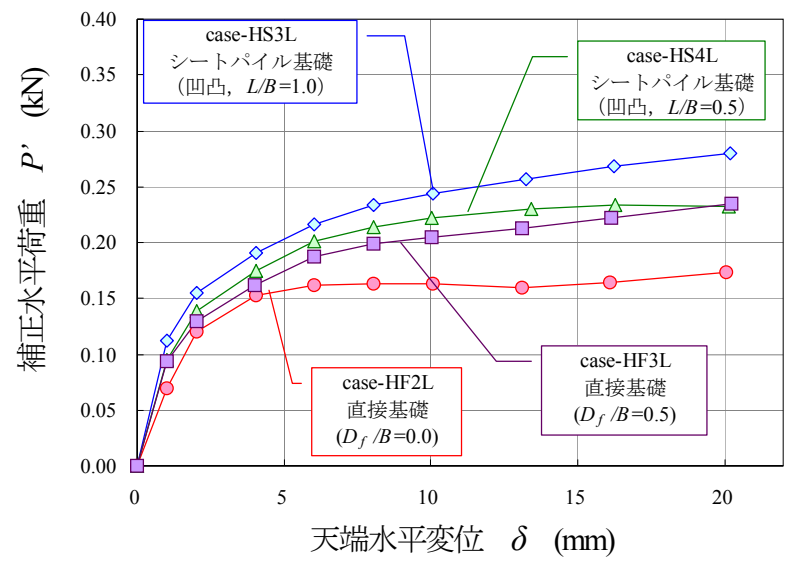

a) 根入れ長さの影響比較 $\left(D_{r}=60 \%\right)$

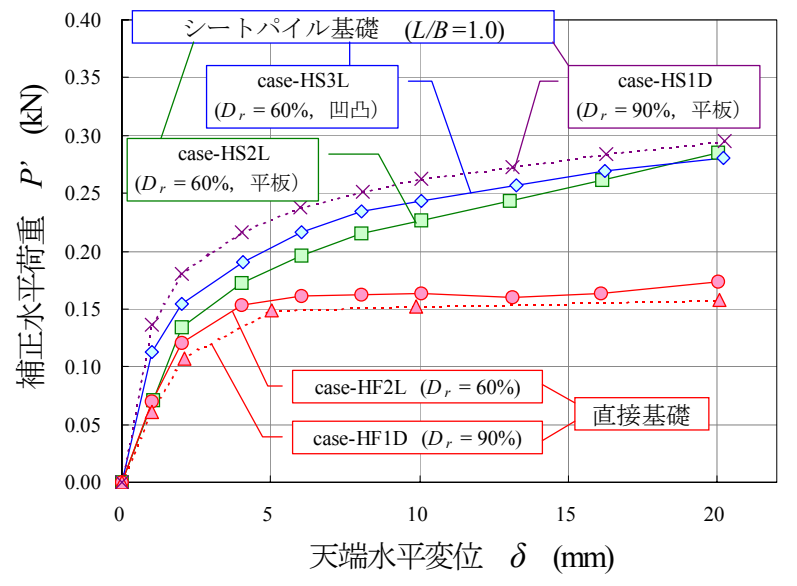

b）シートパイル剛性および地盤密度の影響比較

図-12 水平荷重 $P$ ' 水平変位 $\delta$ 関係（骨格曲線）

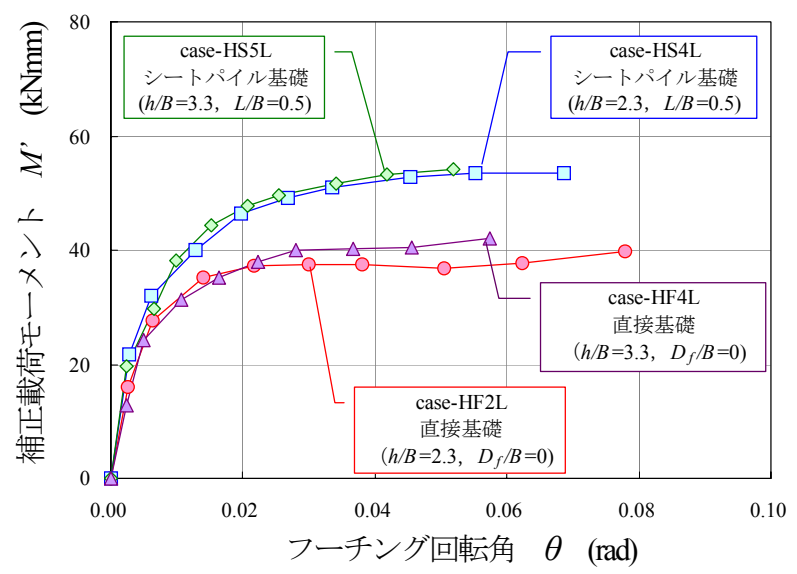

図-13 作用モーメント $M^{\prime}$ ～回転角 $\theta$ 関係（骨格曲線） 


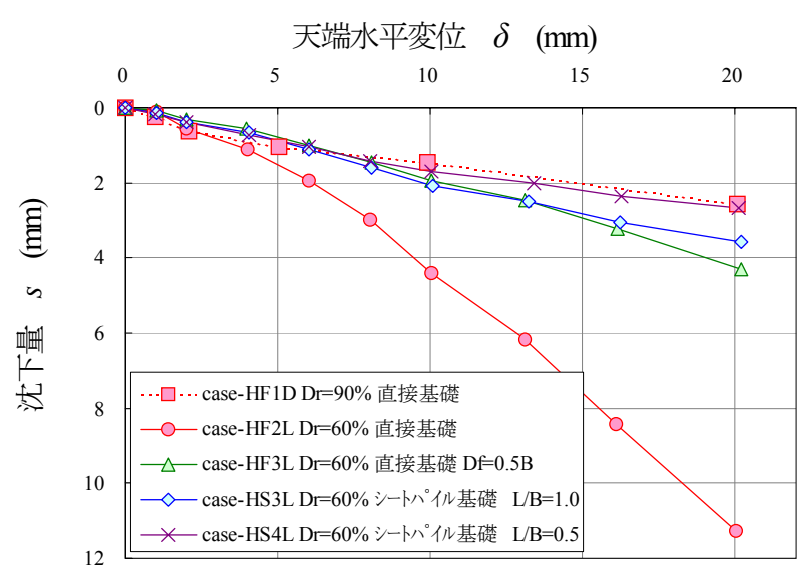

図-14 水平変位 $\delta$ 累積沈下量 $s$ 関係（骨格曲線）

直接基礎 $\left(D_{f}=0 \mathrm{~mm}\right)$ ，シートパイル基礎 $(L=50 \mathrm{~mm})$ ともに載荷高さによらず同等の $M^{\prime}-\theta$ 関係となっており, 実験した範囲では載荷高さは改良効果には大きく影響し ないことが確認できる.

\section{（3）累積沈下量}

図-14 は天端水平変位 $\delta$ とフーチングの沈下量 $s$ (鈆 直ジャッキ変位量) 関係の骨格曲線である.ここで，沈 下量 $s$ は目標鈆直荷重 $V_{0}$ 設定完了時をゼロとしている. この図より, 各ケースとも載荷が進むにつれて沈下が累 積的に進行していることがわかる．特に $D_{r}=60 \%$ の根入 れのない直接基礎（case-HF2L）では沈下が大きく，最 終的に基礎幅の $10 \%$ を超える沈下量が生じている. 一 方，シートパイル基礎（case-HS3L，HS4L）は，根入れ された直接基礎（case-HF4L）や $D_{r}=90 \%$ の直接基礎 (case-HF1D) と同等の沈下量に抑制されていることが わかる. よって, 地盤が緩く直接基礎では沈下が懸念さ れる場合でも，シートパイル基礎とすることで沈下抑制 の改良効果が期待できることがわかる.

\section{（4）回転中心深度}

シートパイル基礎は根入れのない直接基礎のようなフ 一チング底面を回転中心としたロッキング動ではなく， フーチング自体が左右に移動するスウェイ成分が大きく なっており（図-11），根入れされた直接基礎のように 回転中心が深くなっている. 一般に，直接基礎は根入れ が深くなるほど減衰が大きくなり，而震設計上有利とな ることから，ここではシートパイル基礎の応答特性を評 価する指標の一つとして，ロッキング動の回転中心深度 $c$ に着目する. 回転中心深度 $c$ は, 各サイクルの折り返 し点における天端水平変位 $\delta$, フーチング底面水平変位 $u$, 載荷点高さ $h$ から式(6)により算出した（図-15）.

$$
c=h \cdot u /(\delta-u)
$$

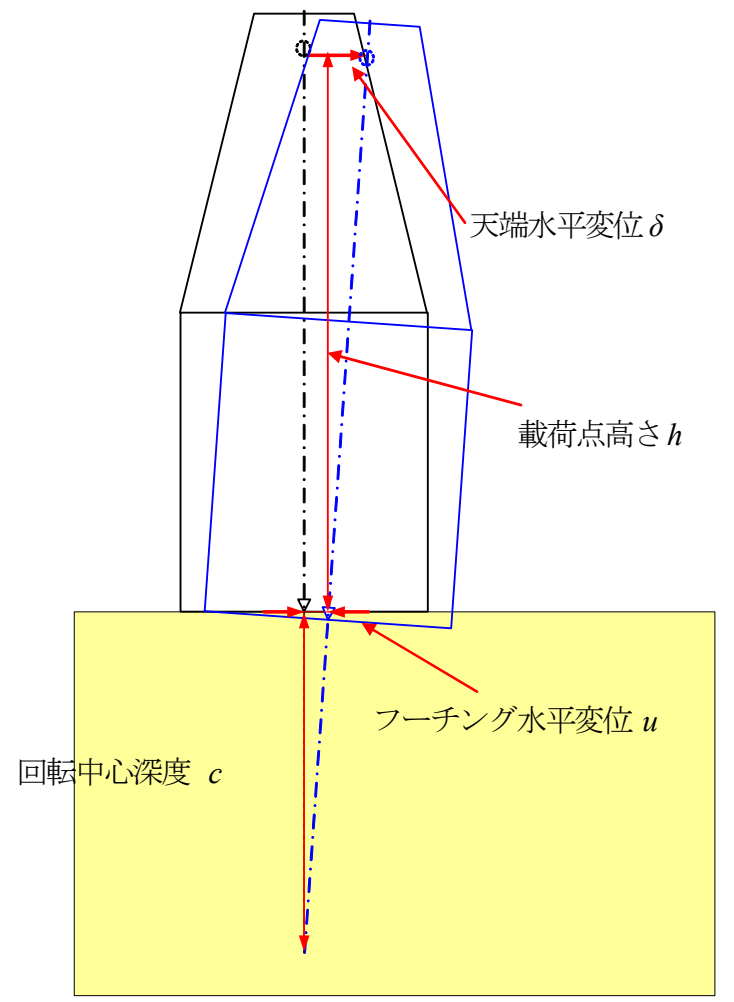

図-15 回転中心深度 $c$

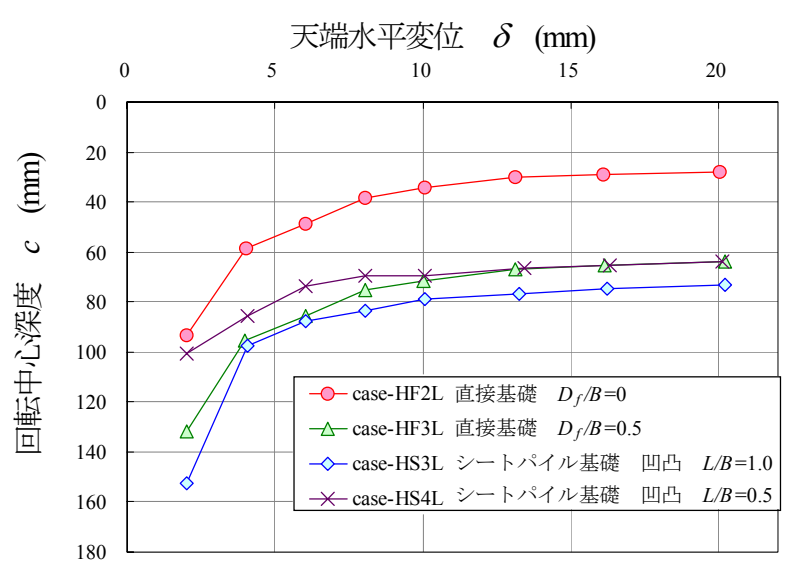

図-16 水平変位 $\delta \sim$ 回転中心深度 $c$ 関係 (骨格曲線)

式(6)により算出した回転中心深度の変化を図-16 に示 す. 載荷初期段階では，いずれもフーチング下 $100 \mathrm{~mm}$ よりも深い位置が回転中心となっているが，載荷が進む につれて回転中心位置が浅くなり，最終的には根入れの ない直接基礎（case-HF2L）で $30 \mathrm{~mm}$ 程度, 根入れした 直接基礎（case-HF3L）およびシートパイル基礎（caseHS3L，HS4L）で60〜80 mm 程度となっている.

以上より，シートパイル基礎の回転中心は根入れされ た直接基礎と同程度に深くなっていることが確認できる.

\section{（5）画像解析による地盤変位計測結果}

画像解析により求めた地盤変位の計測結果を図-17, 図-18 に示寸. 図-17 は水平交番載荷中（試験開始加ら 最終サイクル終了後に天端水平変位量 $\delta=0 \mathrm{~mm}$ に戻した 
時点まで）のメンブレンに記した各標点の全変位軌跡で あり, 図-18 は最大変位 $(\delta=+20 \mathrm{~mm})$ 付近での変位増 分ベクトルを示したものである. ここで，図-18 の変位 増分ベクトルは，天端水平変位 $\delta$ が $+19 \mathrm{~mm}$ から $+20 \mathrm{~mm}$ に増加する間の各標点の地盤変位ベクトルを約 50 倍し て表示している. a)～C) はそれぞれ， $D_{r}=60 \%$ の根入れ のない直接基礎（case-HF2L），根入れのある直接基礎

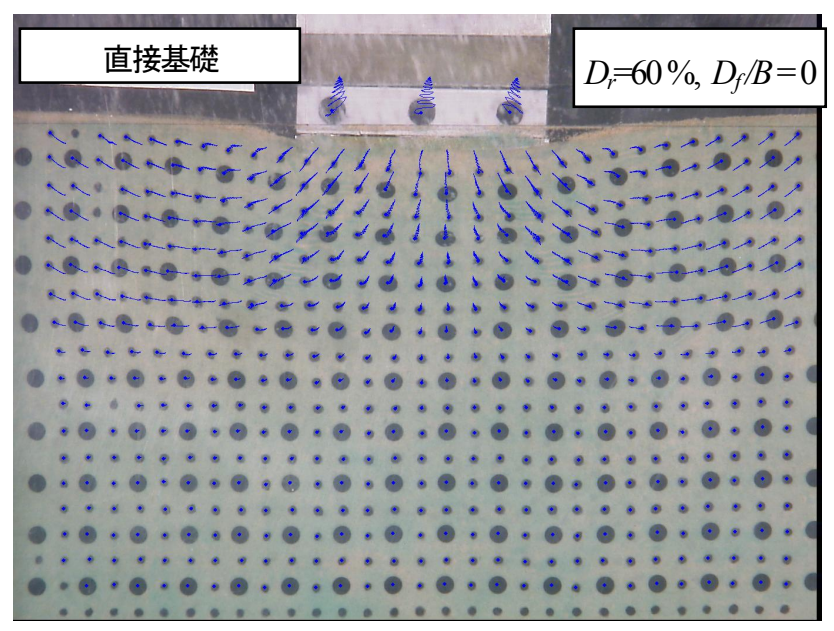

a) case-HF2L

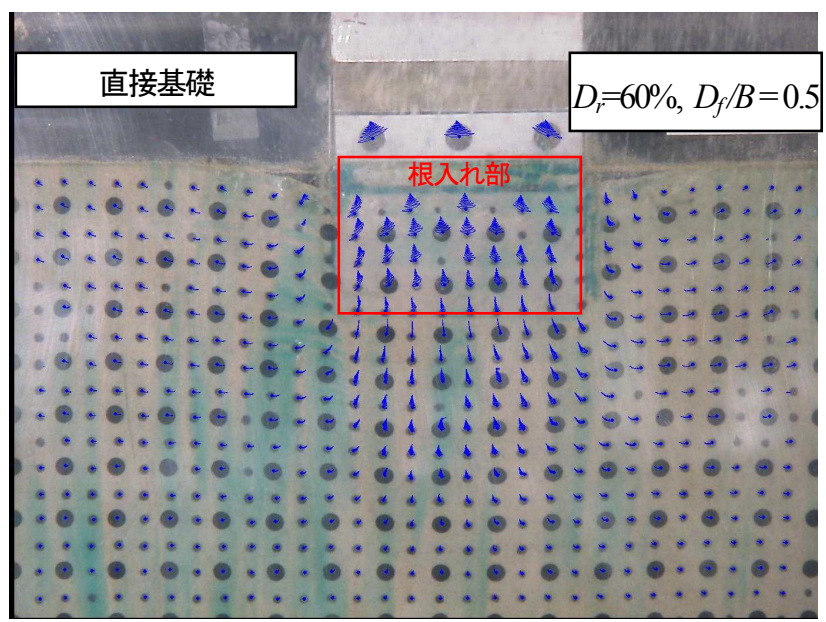

b) case-HF3L

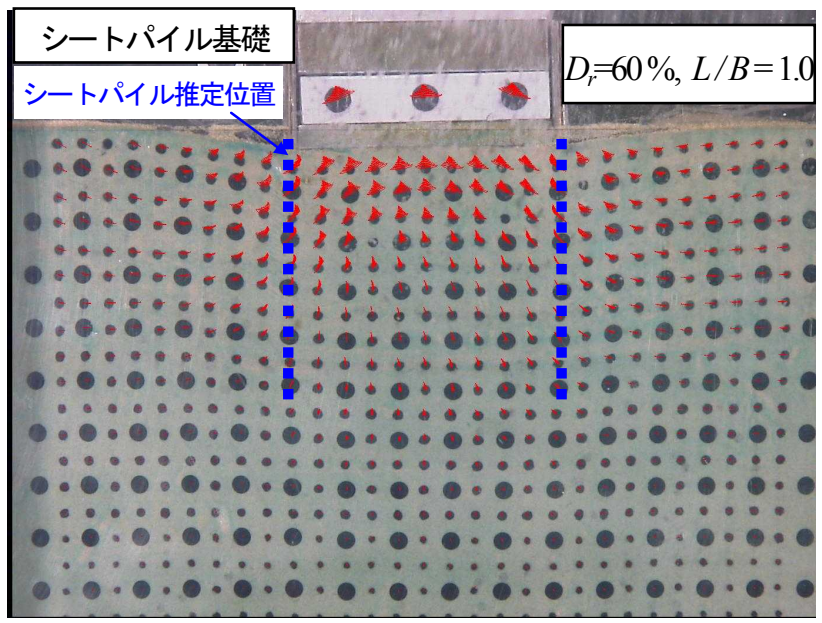

c) case-HS3L

図-17 画像解析により求めた地盤変位軌跡
（case-HF3L），シートパイル基礎（case-HS3L）である. シートパイル基礎については，シートパイル模型の曲げ 変形を無視した推定位置を点線で図中に記した。

図-17 a)の根入れのない直接基礎（case-HF2L）では, 基礎直下地盤は左右に広がりながら全体的に沈下し，そ の外側は円弧すべり状に変位している．図-18 a)の変位 ベクトルからも，フーチングの端部地盤の支持降伏に伴

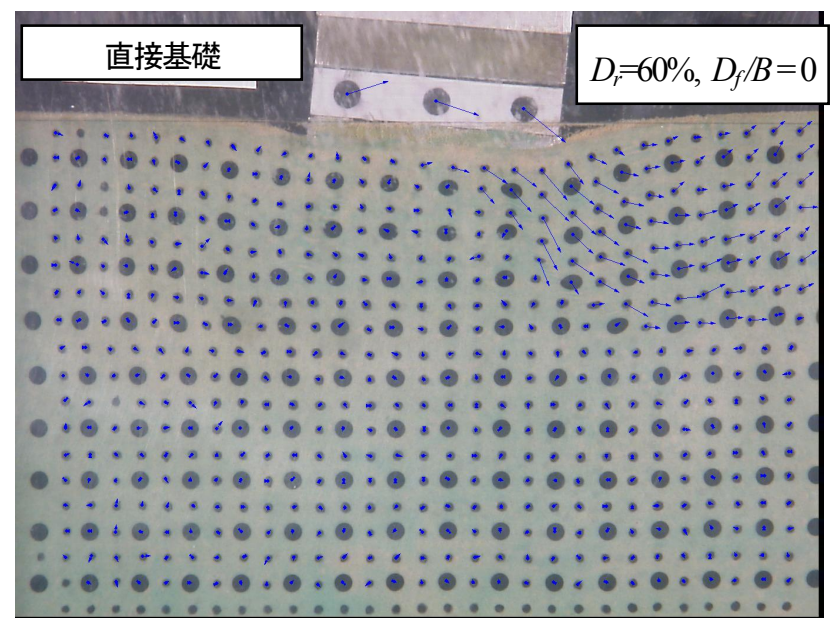

a) case-HF2L

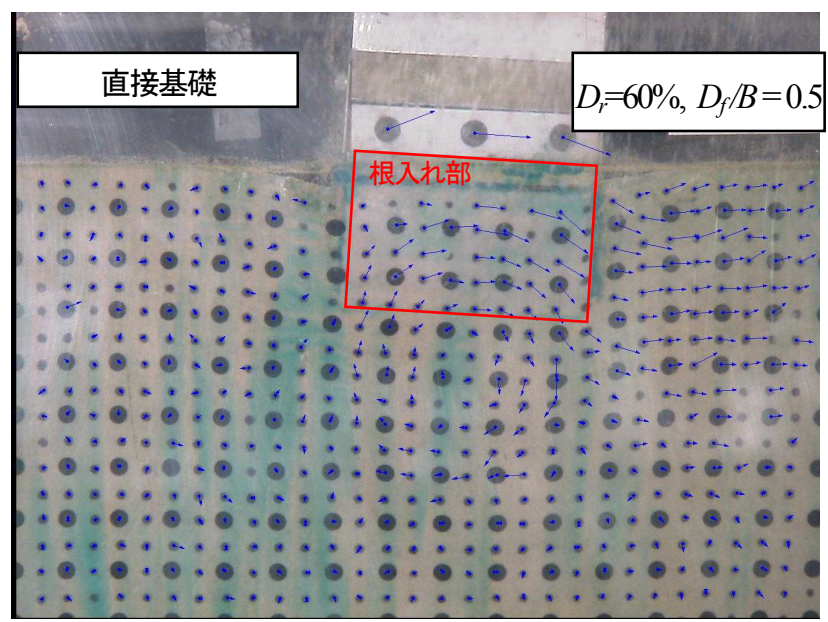

b) case-HF3L

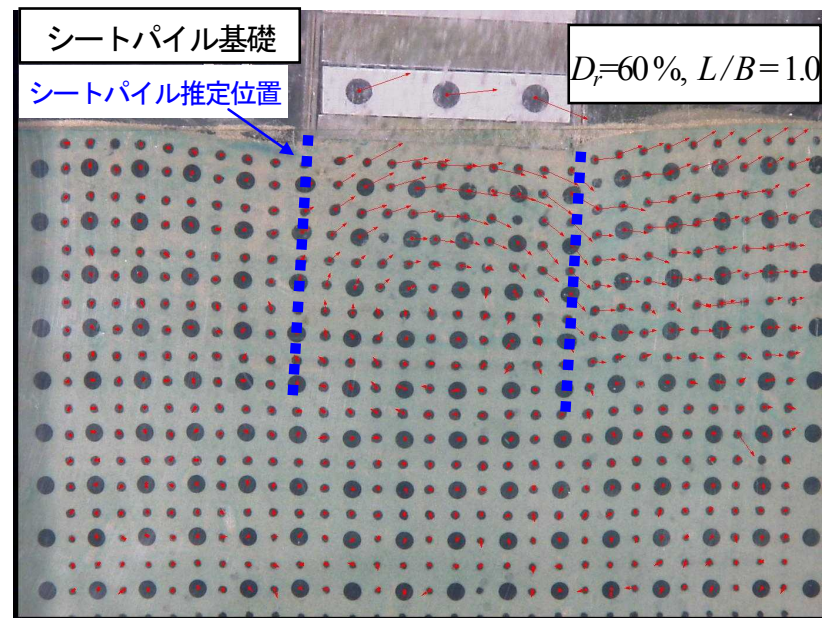

c) case-HS3L

図-18 最大変位付近での地盤変位増分ベクトル 
う破壊領域で円弧すべり状の大きな変位が生じているこ とがわかる．このような円弧すべり状の地盤変位は，鈆 直載荷試験の場合でも観察されるが，鉛直載荷試験では フーチング幅よりも深い領域まで地盤変位が生じる ${ }^{21} の$ に対して, 水平交番載荷では偏心および浮き上がりに伴 って載荷有効幅が狭くなるため, 図-17 a) で確認できる ように，地盤変位が生じる領域が浅い範囲（およそ基礎 幅以浅) に限定されるのが特徽といえる.

図-17 b) の根入れのある直接基礎（case-HF3L）では, 地盤変位の生じる領域が深い領域となり, 変位量自体も 根入れのない場合に比べて小さくなっている. 図-18 b) からは，根入れ部分が底面付近を中心にして剛体回転し ており, 図-16 で示した回転中心深度が深くなっている 状況が確認できる. また, 根入れ部分の前面の地盤には, 根入れがない場合（図-18 a)）のような上向きの変位は 見られず，ほぼ一様に水平方向に変位している.

図-17 c)のシートパイル基礎（case-HS3L）の地盤変位 軌跡を見ると, シートパイルの内側の地盤の左右一の広 がりは図-17 a)よりも小さく, シートパイルの外側では, 図-17b)の根入れのある直接基礎と同様に水平方向に一 様な変位が生じている. 寸なわち，シートパイルが円弧 状のすべり線を遮断するように抵抗し，フーチング直下 地盤の外側へのはらみ出しを拘束して沈下量の累積を抑 制していることがわかる.

一方，図-18 c)のシートパイル基礎（case-HS3L）の地 盤変位ベクトルを見ると, 全体的に図-18 b) の根入れの ある直接基礎と同様に回転中心深度が深くなっているこ とがわかる．特に背面側（載荷方向と反対側）のフーチ ング直下地盤が斜め右上方に変位しており, 根入れのな い直接基礎とは異なる挙動を示している. 寸なわち, 各 載荷サイクル内においては, 背面側シートパイルがフー チング直下地盤を受働側（斜め右上方）に変位させ，シ ートパイルの内側の地盤はフーチングと一体化して動い ていることがわかる.

\section{(6) フーチング底面の反カ}

図-19 にフーチング底面に 5 分割して配置した 2 方向 ロードセルで計測した底面反力度を示す. $D_{r}=60 \%$ の根 入れのない直接基礎（case-HF2L）とシートパイル基礎 (case-HS3L) について, 最大変位時 $(\delta=+20 \mathrm{~mm}$ 時) の 底面鉛直応力度 $p$ および底面せん断応力度 $\tau$ から, 底面 反力度ベクトルとして表示した．また，同時に基礎に作 用する鉛直ジャッキ荷重 $V$, 補正水平荷重 $P$, およびフ 一チングの底面積 $A_{f}$ から求めた平均応力ベクトル $\left(V / A_{f}\right.$, $\left.P^{\prime} / A_{f}\right)$ および偏心距離 $e_{x}=M^{\prime} / V$ も同時に示した。 なお, シートパイル基礎の底面せん断応力は, 直前の水平荷重 $P^{\prime}=0 \mathrm{kN}$ 時から $\delta=+20 \mathrm{~mm}$ に到達するまでのせん断応力

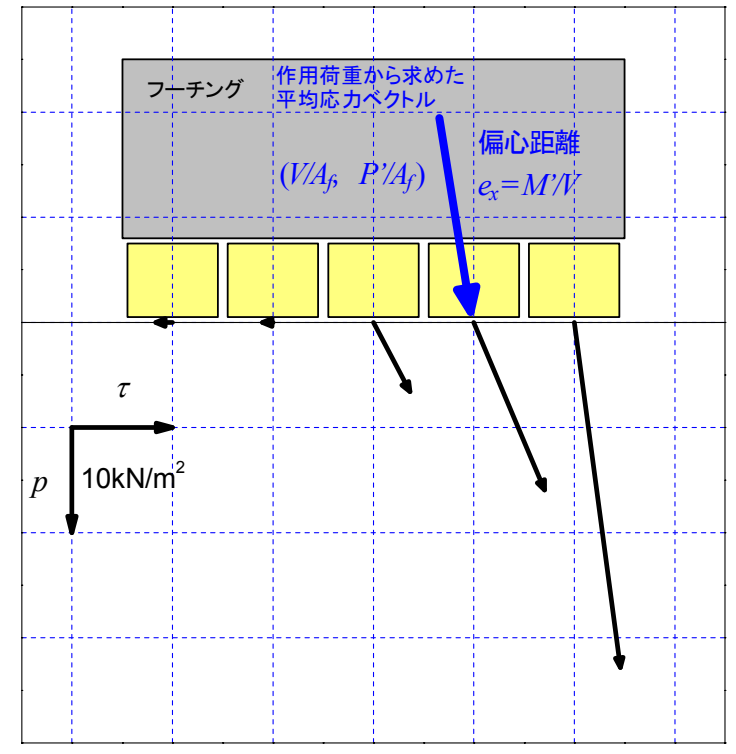

a) 直接基礎（case-HF2L，Df $B=0$ ）

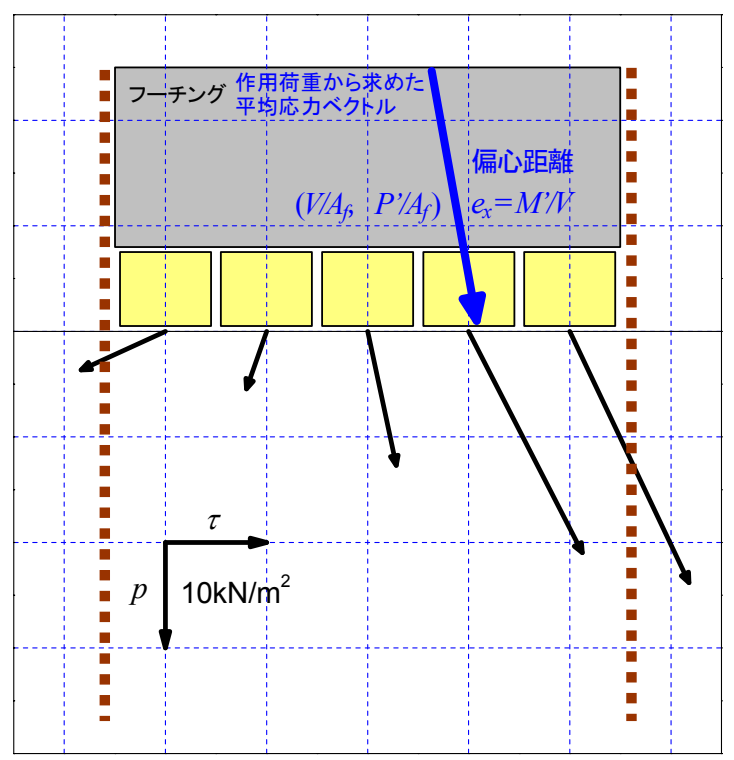

b) シートパイル基礎（case-HS3L，凹凸， $L / B=1.0$ ）

図-19 底面反力分布 $\left(\delta=20 \mathrm{~mm}\right.$ 時, $\left.D_{r}=60 \%\right)$

の増加分でベクトルを図示した．これは，水平変位の正 負逆転時にロードセルとシートパイルの間に徐々に砂が 入り込み，載荷サイクル毎に計測值が漸増した影響を除 去するための処置である.

図-19 a)の直接基礎では, 前面側（主に外側の地盤か らの土圧を受ける側）の端部に地盤反力が集中しており， 底面反力が大きく偏心していることがわかる．また，背 面側て鉛直地盤反力がゼロとなっており，浮き上がりが 生じている. 一方, 図-19 b)のシートパイル基礎では, 鉛直反力は前面側に集中するもののその程度は直接基礎 よりも小さく，底面反力の偏心量は比較的小さい．また， 背面側の鉛直反力が残っており，浮き上がりは生じずに， 地盤との接触を保持していることがわかる. 


\section{（7） シートパイルの曲げ変形}

模型シートパイルの頭部（フーチング底面から $10 \mathrm{~mm}$ 下）に貼付したひずみゲージから計測した頭部曲率と天 端水平変位 $\delta$ の関係の履歴曲線を case-HS3L（凹凸模型， $L / B=1.0 ）$ について, 曲率の正負の定義とともに図-20 に示す，載荷が進むにつれて，右側で正の曲率，左側で 負の曲率が累積しており, 徐々に外側に広がるように変 形が進んだことがわかる。これは，シートパイルに囲ま れた土塊がはらみ出すように広がって，シートパイルが 外側に押し出されたためと考えられ，図-18 c) の地盤変 位軌跡と合致する。

\section{4. 考察}

本章では，シートパイル基礎の改良効果発現メカニズ ムについて考察を行う。まず，抵抗要素を分離して評価 寸るため, 図-21 に示すようにシートパイル基礎の抵抗 成分を分解して整理する。 ここで，図-21 中の各記号は

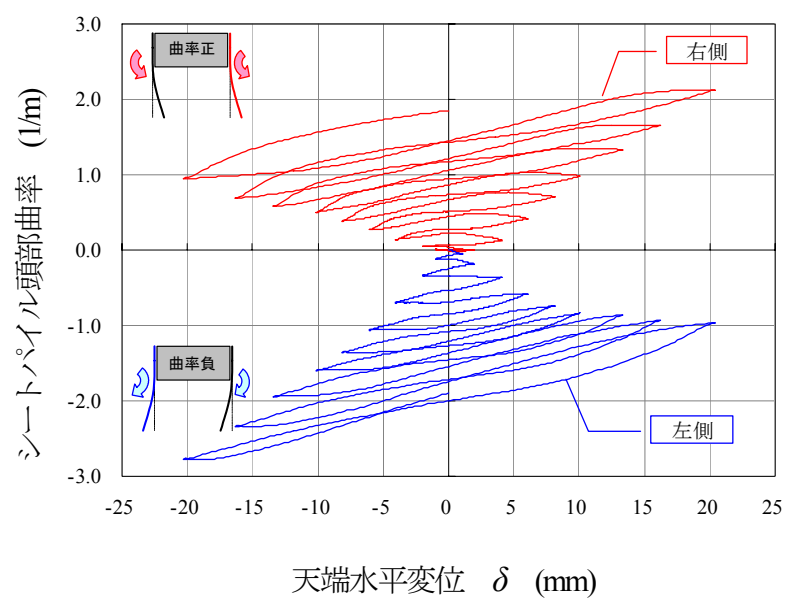

以下に示寸とおりである。 なお，本論文では，載荷側と 反力側での比較が容易となるよう，それぞれ符号を一致 させて示す (図中の矢印の方向を正とする) .

\section{<鉛直力 >}

$V:$ 鉛直ジャッキ荷重

$V_{f}:$ フーチング底面での鉛直反力

$N_{R}, N_{L}$ : シートパイル頭部の鉛直反力（軸力）

\section{<水平力 $>$}

$P^{\prime}:$ 補正水平荷重

$H_{f}:$ フーチング底面での水平反力

$Q_{R}, Q_{L}$ : シートパイル頭部の水平反力（せん断力）

\section{〈モーメント >}

$M^{\prime}\left(=P^{\prime} \times h\right)$ : 補正載荷モーメント（ $h$ : 載荷高さ $)$

$M_{f}:$ フーチング底面での反力モーメント

$M_{R}, M_{L}$ : シートパイル頭部での曲げモーメント

$M_{N}$ : シートパイル頭部での鋁直反力の差によるフーチ ング中心回りの偶力モーメント（左右合計）

\section{（1） フーチング底面反力の負担}

シートパイル基礎の抵抗成分のうち，フーチング底面 反力について比較する. フーチング底面での鉛直反力 $V_{f}$, 水平反力 $H_{f}$, 反力モーメント $M_{f}$ は，5分割した各ロード セルの鉛直応力度 $p$ およびせん断応力度 $\tau$ から, 次式に より算出した.

$$
\begin{aligned}
& V_{f}=p_{\text {ave }} \cdot A_{f} \\
& H_{f}=\tau_{\text {ave }} \cdot A_{f} \\
& M_{f}=\sum_{i=1}^{5}\left(p_{i} \cdot \Delta w \cdot D \cdot \ell_{i}\right)
\end{aligned}
$$

図-20 頭部曲率～水平変位関係（case-HS3L）

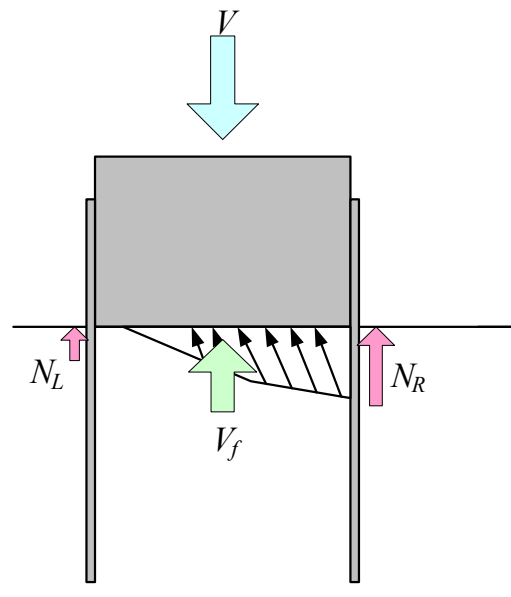

a) 鉛直力

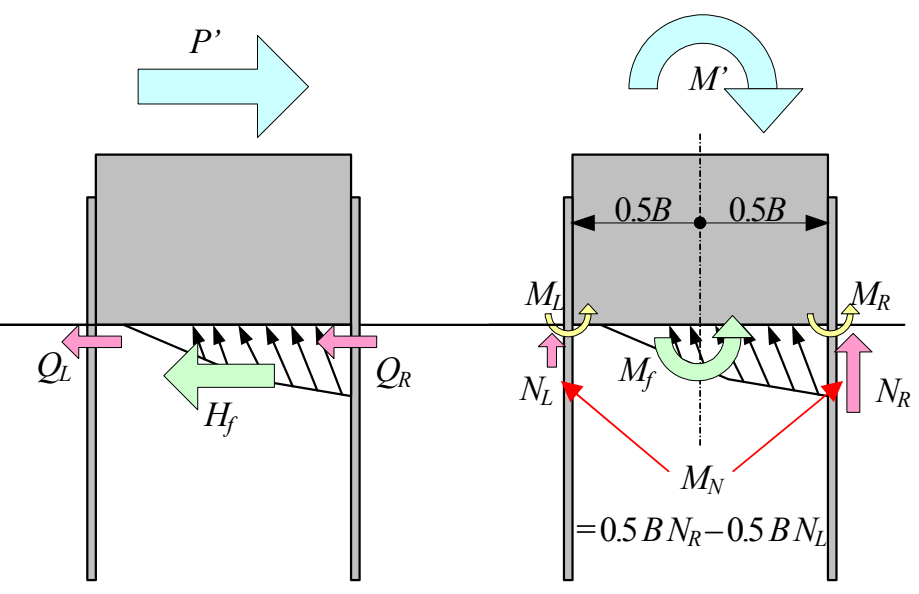

b) 水平力

c）モーメント

図-21 シートパイル基礎の抵抗成分の分解 
ここで, $p_{i}: i$ 番目の底面ロードセルによる鉛直応力度, $p_{a v e}: p_{i}$ の平均值, $\tau_{a v e}$ : 底面ロードセルによるせん断応 力度の平均值, $\Delta w$ : 底面ロードセルの受圧板幅 $(20$ $\mathrm{mm}), \quad \ell_{i}: i$ 番目の底面ロードセル中心からフーチン グ中心までの距離, $D$ : フーチングの奥行き（600 mm）, $A_{f}$ : フーチングの底面積 $\left(6,000 \mathrm{~mm}^{2}\right)$ である. なお，底

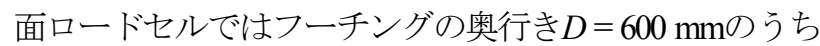
中央部 $200 \mathrm{~mm}$ の受圧板区間（図-4）しか計測できてい ないが，式(7)〜(9)では奥行き方向に均一の底面反力が 発生しているものと仮定した。 このため, 底面反力分布 の奥行き方向の不均一性による誤差が含まれることに注 意を要する．例えばcase-HF3Lの直接基礎では，式(7)に より求めた鉛直反力 $V_{f}$ と鉛直ジャッキ荷重 $V$ の誤差は 約 $20 \%$ 程度であった。

式(7)より求めたシートパイル基礎のフーチング底面 鉛直反力 $V_{f}$ の負担比率（鉛直ジャッキ荷重 $V$ との比）の 骨格曲線（正負両側平均）を図-22に示す。いずれのケ 一スにおいてもフーチング底面では40～60\%程度を負担 しつづけたことがわかる. また，シートパイルの短い方 がフーチング底面の負担比率が高くなっており，シート パイルの鈆直支持力の違いが影響していると考えられる.

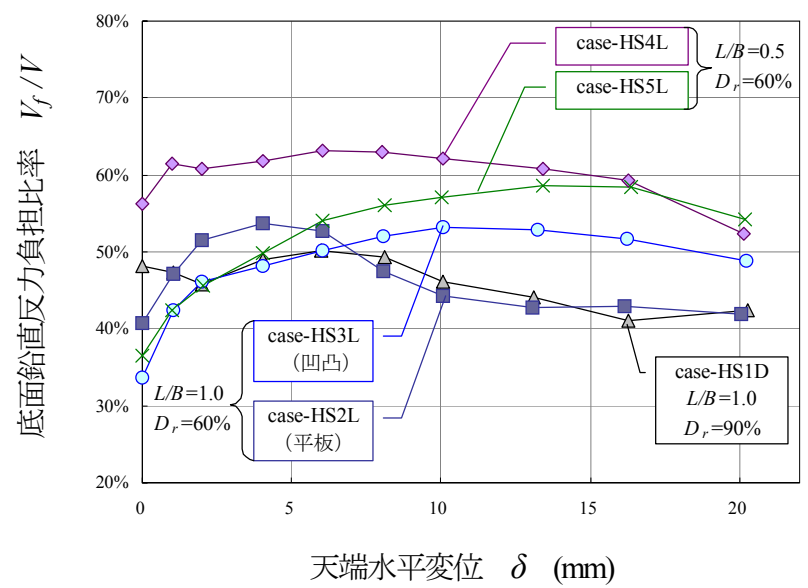

図-22 底面鉛直反力負担比率～天端水平変位関係

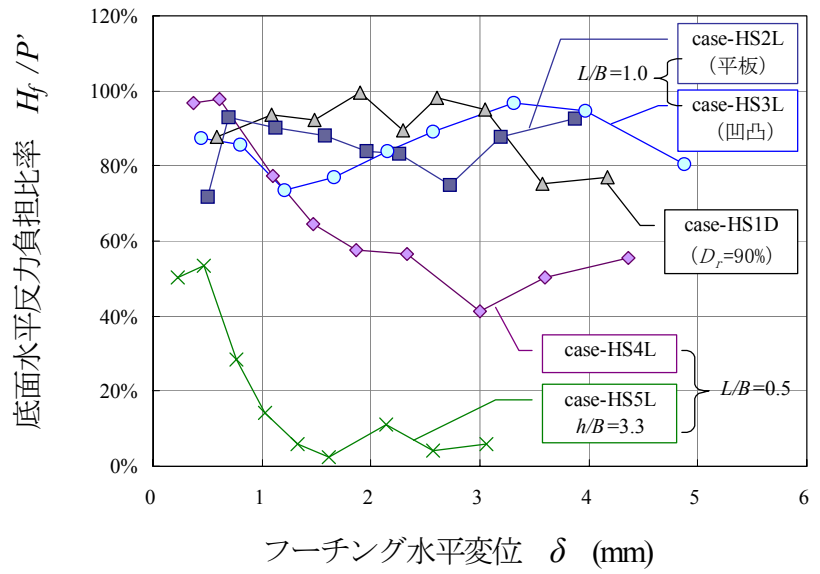

図-23 底面水平反力負担比率〜フーチング水平変位関係
次に, 式(8)より求めたフーチング底面での水平反力 $H_{f}$ の負担比率（補正水平荷重 $P^{\prime}$ との比）とフーチング 水平変位 $u$ の骨格曲線（正負両側平均）を図-23に示す. この図では，シートパイルが長いほど負担比率は大きく なっているが，これはシートパイルが長いほどシートパ イルで囲まれた地盤とフーチングとの一体性が高まるた めと考えられる. また，載荷高さが高い方が負担比率は 小さくなっているが，これは載荷高さが高いほどフーチ ング底面の浮き上がりが生じやすいためと考えられる.

式(9)により求めた底面反力モーメント $M_{f}$ については, フーチング回転角 $\theta$ との関係を骨格曲線（正負両側平 均）で図-24に示す。また，比較のため，直接基礎 (case-HF2L) の補正載荷モーメント $M$ も同時に示す. この図よりシートパイル基礎の底面反力モーメントは直 接基礎よりも小さく，当然ながらシートパイル基礎の補 正載荷モーメント $M$ よりも小さい抵抗となっている. これは，図-19 b)で示した底面反力分布の偏心量が小さ いことと合致する。 また，底面反力モーメント $M_{f}$ はシ 一トパイルが短いほど大きくなっており，シートパイル が短いほどフーチング底面での鉛直反力の負担比率が大 きい(図-22）ことの影響と考えられる.

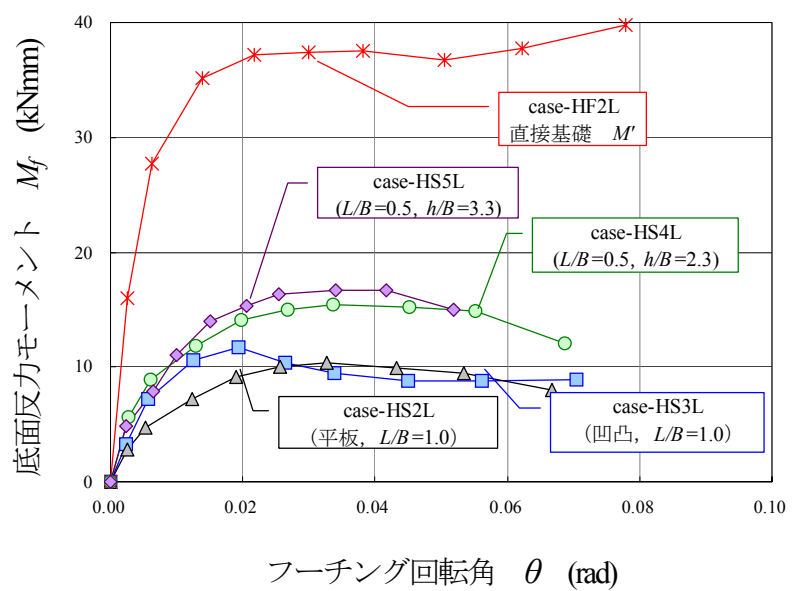

図-24 底面反力モーメント〜回転角関係 $\left(D_{r}=60 \%\right)$

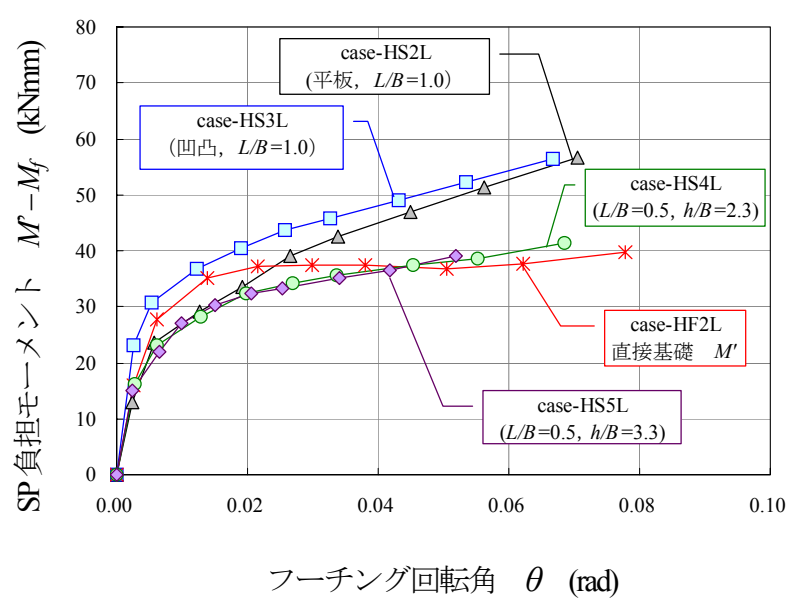

図-25 シートパイル負担モーメント〜回転角関係 


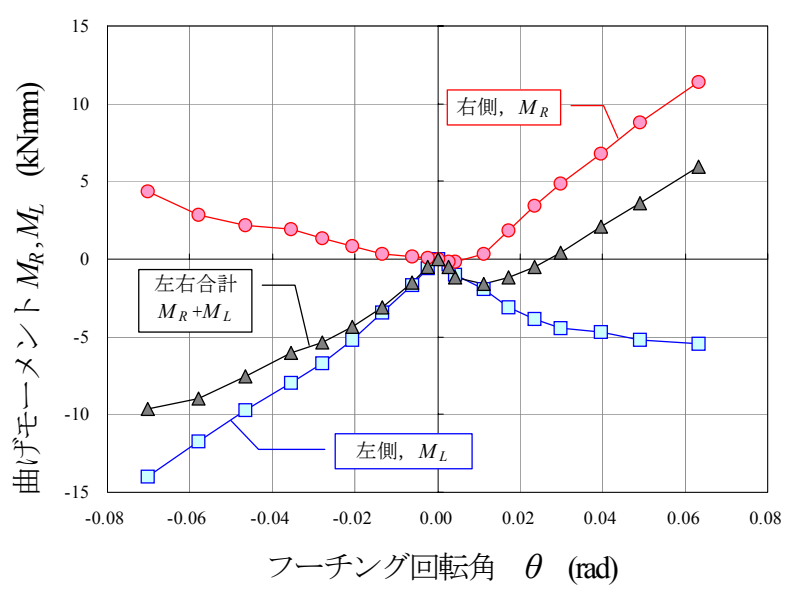

図-26＼cjkstart曲げモーメント〜水平変位関係（case-HS3L）

\section{（2）シートパイルの負担モーメント}

シートパイルが負担する全モーメントを，載荷補正モ 一メント $M^{\prime}$ とフーチング底面反力モーメント $M_{f}$ の差 $\left(M^{\prime}-M_{f}\right)$ として求め, 図-25に示す. また, 比較のた め, 直接基礎（case-HF2L）の補正載荷モーメント $M$ も 同時に示す。この図より，シートパイルが負担する全モ 一メントは直接基礎の補正載荷モーメント $M$ と同等以 上の抵抗力を負担し，降伏時で $20 \sim 30 \mathrm{kNmm}$ と，フー チング底面反力モーメント $M_{f}(10 \sim 15 \mathrm{kNmm}$, 図-24) の2倍以上となっていることがわかる.

一方，ひずみ計測結果から求めたシートパイル頭部の 曲げモーメントをcase-HS3L（凹凸模型， $L / B=1.0$ ）につ いて図-26に示す. 曲げモーメントの正負は, フーチン グ底面反力モーメント $M_{f}$ 等と正負の方向が一致するよ うに図-21中の矢印の方向を正として示している. 図-20 に示したように，左右のシートパイルはそれぞれ外側に 開き出すように累積的に変形しているため，両者を合計 したシートパイル曲げ負担分モーメントとしては，それ ぞれ打ち消し合う傾向にあることがわかる．なお，他の ケースでは曲げモーメントはさらに小さく, 左右を合計 するといずれも $3 \mathrm{kNmm}$ 未満であった.

\section{（3）抵抗成分別の負担比率の比較}

各抵抗成分の負担比率を比較するため, 降伏変位付近 として $\delta=4 \mathrm{~mm}$ 時および終局時として $\delta=20 \mathrm{~mm}$ 時での, 各負担モーメントの比率を図-27に示す。ここで，直接 基礎（根入れなし, case-HS2L）は補正載荷モーメント $M^{\prime}$ を底面負担分として示した。 また，本研究ではシー トパイルの頭部軸力が計測できなかったため，シートパ イル軸力負担分モーメント $M_{N}$ を直接的には計測できて いないが，ここでは補正載荷モーメント $M$ ’からフーチ ング底面負担分 $M_{f}$ とシートパイルの曲げ負担分 $\left(M_{R}+M_{L}\right)$ を引いて求めた。

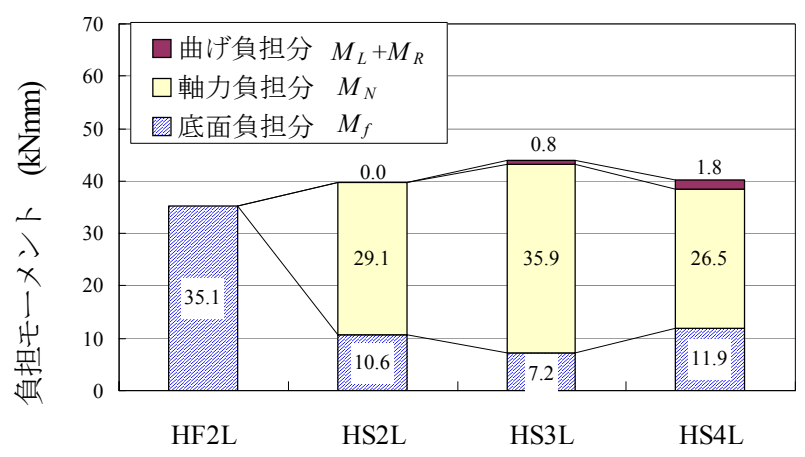

a) $\delta=4 \mathrm{~mm}$ 時（降伏付近, $D_{r}=60 \%, h / B=2.3$ )

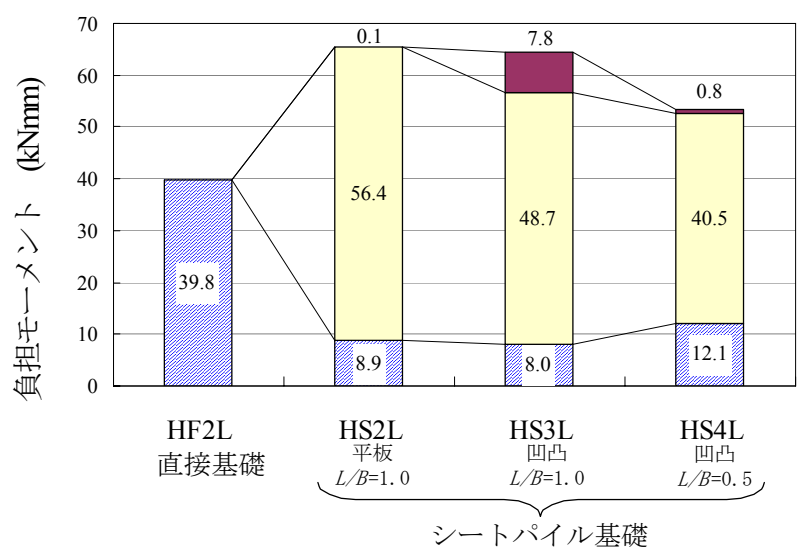

b) $\delta=20 \mathrm{~mm}$ 時（終局時, $D_{r}=60 \%, h / B=2.3$ )

図-27 負担比率の比較

図-27から全体の抵抗モーメントに対して，シートパ イルの軸力による偶力モーメント $M_{N}$ の負担比率が高い ことがわかる．逆にシートパイルの曲げモーメント分

$\left(M_{R}+M_{L}\right)$ の負担比率は小さく, 特にシートパイルの 曲げ岡性の低い平板模型のケース（case-HS2L）ではほ とんどゼロとなっている. 一方, フーチング底面の反力 モーメント $M_{f}$ は，全抵抗モーメントの $15 ２ 5 \%$ 程度を 負担しており，シートパイルの根入れ長さが短い方 (case-HS4L， $L / B=0.5$ ) が, その負担比率が高い. 底面 反力モーメント $M_{f}$ は直接基礎に比べると $20 \sim 35 \%$ 程度 の值しか発揮されていないが，シートパイル基礎の改良 効果を評価する上ではこのフーチング底面での反力モー メント $M_{f}$ を無視することができないことがわかる.

図-27から降伏付近（ $\delta=4 \mathrm{~mm}$ 時）から終局時 $(\delta=20$ $\mathrm{mm}$ 時）までの間では，軸力による偶力モーメント $M_{N}$ が増加し, フーチング底面の反力モーメント $M_{f}$ はほと んど変化していないことがわかる.このほか, 図-24の シートパイル基礎の底面反力モーメント $M_{f}$ には降伏後 の 2 次勾配がほとんどみられず，直接基礎と同様の傾 向である.また，図-25のシートパイルが負担する全モ 一メントには降伏後の 2 次勾配があり, シートパイルの 
根入れ長さが長いほど 2 次勾配が大きい傾向がみられる. これらのことから，シートパイル基礎の降伏後の 2 次 勾配（抵抗力の増加）は，シートパイルの軸力の増加に 起因するものと考えられる.

\section{（4） シートパイルの発生軸力と支持力の比較}

ここでは, シートパイルの軸力について, 発生軸力お よび鉛直抵抗力（鉛直支持力）の両面から考察する.

まず，水平載荷時に発生する左右のシートパイルの頭 部軸力 $N_{R}, N_{L}$ を求める. 本研究ではシートパイルの頭部 軸力を計測することができなかったため，偶力モーメン ト $M_{N}$ からこれらを概算する. 力の釣り合いから， $M_{N}$ お よび $N_{R}, N_{L}$ は，以下の関係式を満足する.

$$
\begin{aligned}
& N_{R}-N_{L}=M_{N} / 0.5 B \\
& N_{R}+N_{L}=V_{0}-V_{f}=V_{0}\left(1-V_{f} / V_{0}\right)
\end{aligned}
$$

case-HS3L $\left(D_{r}=60 \%, L=100 \mathrm{~mm}\right)$ について，図-22よ り底面反力比 $V_{f} / V=0.5\left(V \fallingdotseq V_{0}=1.2 \mathrm{kN}\right)$ ，図-27より偶

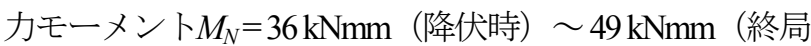
時）とすると，左右シートパイルの発生軸力は，押込み 側で $0.65 \sim 0.8 \mathrm{kN}$ ，引抜き側で $-0.05 \sim-0.2 \mathrm{kN}$ と推定され る.

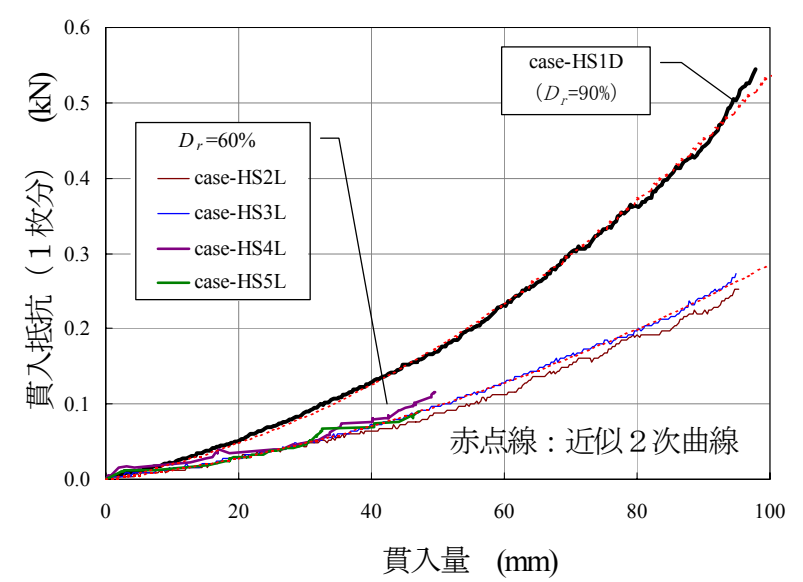

図-28模型シートパイルの貫入抵抗

表-3 シートパイルの発生軸力と支持力

\begin{tabular}{|c|c|c|c|}
\hline \multicolumn{2}{|c|}{$\begin{array}{c}\text { case-HS3L } \\
\left(D_{r}=60 \%, L=100 \mathrm{~mm}\right)\end{array}$} & $\begin{array}{c}\text { 前面側 } \\
\text { (押込み側) }\end{array}$ & $\begin{array}{c}\text { 背面側 } \\
\text { (引抜き側) }\end{array}$ \\
\hline \multirow{4}{*}{$\begin{array}{c}\text { 発生 } \\
\text { 軸力 }\end{array}$} & $\begin{array}{c}\delta=0 \mathrm{~mm} \text { 時 } \\
\text { 水平載荷前 }\end{array}$ & \multicolumn{2}{|c|}{$0.3 \mathrm{kN}$} \\
\cline { 2 - 4 } & $\begin{array}{c}\delta=+4 \mathrm{~mm} \text { 時 } \\
\text { 降伏付近 }\end{array}$ & $0.65 \mathrm{kN}$ & $\begin{array}{c}-0.05 \mathrm{kN} \\
\text { (引張 })\end{array}$ \\
\cline { 2 - 4 } & $\begin{array}{c}\delta=+20 \mathrm{~mm} \text { 時 } \\
\text { 終局時 }\end{array}$ & $0.8 \mathrm{kN}$ & $\begin{array}{c}-0.2 \mathrm{kN} \\
\text { (引張) }\end{array}$ \\
\hline \multirow{2}{*}{ 支持力 } & 貫入時 & $0.3 \mathrm{kN}$ & \\
\cline { 2 - 4 } & 模型撤去時 & & ほぼゼ口 \\
\hline
\end{tabular}

一方，シートパイルの鉛直支持力自体は，模型シート パイル貫入時（図-8 a）設置手順<1>）の抵抗から求め ることができる．模型シートパイル貫入時の荷重変位関 係を図-28に示す，なお，貫入に際しては左右のシート パイルを同時に貫入しているが，図-28では貫入抵抗を1 / 2して 1 枚分の值として示している. 図-28より貫入抵 抗は地盤密度の影響が大きく，断面形状（可凸の有無） の影響は小さいことがわかる. 鋼矢板の鋁直支持力特性 に関する研究では, 屈曲形状に起因した先端閉塞効果が 生じることが報告されているが38，本実験では凹凸高さ と幅の比（凹凸高さ $1.5 \mathrm{~mm} /$ 凹凸幅 $10 \mathrm{~mm}=0.15$ ）が実

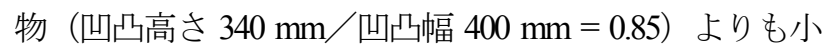
さいために，閉塞効果はほとんど発揮されなかったと考 えられる. $D_{r}=60 \%, L=100 \mathrm{~mm}$ の場合 (case-HS3L, 凹 凸模型）の一枚あたりの貫入抵抗（鉛直支持力）は 0.3 $\mathrm{kN}$ 程度であることがわかる．また，引き抜き抵抗（引 き抜き支持力）は正確には計測していないものの，試験 終了後に模型を引き上げて撤去した時の荷重は非常に小 さい值であった.

以上のシートパイルの発生軸力および支持力を caseHS3Lについて表-3にまとめて示す。式(10)，(11)から逆 算したシートパイルの発生軸力は，水平載荷前の目標鉛 直荷重 $V_{0}=1.2 \mathrm{kN}$ を作用させた段階で既に貫入時の鉛直 支持力（ $0.3 \mathrm{kN})$ に至っており，水平載荷時の発生軸力 は押込み側，引き抜き側とも貫入時および模型撤去時の 鈆直抵抗力を上回る軸力が発生したこととなる. シート パイル基礎の抵抗モーメントは偶力モーメント $M_{N}$ が主 体である（図-27）ことから，このように鉛直支持力の 上昇（貫入時の鉛直支持力を上回る軸力の発生）により 非常に大きな偶力モーメント $M_{N}$ を発揮することが，シ 一トパイル基礎の改良効果発現上で，重要なメカニズム の一つと考えられる.

\section{（5） シ一トパイルの鉛直支持カの上昇メカニズム}

本研究では，シートパイルの軸力が計測できなかった ため，前節に示すように実際に鉛直支持力が上昇するこ とを十分に実証できていない. しかしながら，既往の研 究事例 ${ }^{39)}$ でも傾斜荷重（鉛直荷重と水平荷重の組み合わ せ）に対する杭の支持力が単独の支持力よりも増大する ことが模型実験により確認されており，傾斜荷重に対す る杭の支持力上昇の要因の一つとして周面摩擦力の影響 が指摘されている. ここでは, 前節に示すシートパイル の鉛直抵抗力上昇メカニズムが，シートパイルと地盤と の接触圧 (すなわち水平土圧) の上昇に伴う周面摩擦力 の上昇であると仮定する. そして，支持力公式に基づく 鉛直支持力のモデル化を行い，画像解析による地盤变位 計測結果やフーチング底面反力分布から上記仮定の検証 を行う。 
表-4＼cjkstart模型シートパイルの貫入抵抗の近似結果

\begin{tabular}{|c|c|c|c|c|c|c|c|c|c|c|c|c|}
\hline \multirow[b]{2}{*}{ case } & \multirow[b]{2}{*}{$\begin{array}{c}\text { 相対密度 } \\
D_{r}\end{array}$} & \multirow{2}{*}{$\begin{array}{l}\text { 断面 } \\
\text { 形状 }\end{array}$} & \multirow{2}{*}{$\begin{array}{l}\text { 根入れ } \\
\text { 長さ } L\end{array}$} & \multicolumn{3}{|c|}{ 1次項（先端抵抗分） } & \multicolumn{4}{|c|}{ 2次項（周面摩擦分） } & \multicolumn{2}{|c|}{ 全体抵抗 } \\
\hline & & & & $\begin{array}{c}\alpha_{1} \\
(\mathrm{kN} / \mathrm{m})\end{array}$ & $\lambda$ & $\begin{array}{c}R_{p} \\
(\mathrm{kN})\end{array}$ & $\begin{array}{c}\alpha_{2} \\
\left(\mathrm{kN} / \mathrm{m}^{2}\right)\end{array}$ & $\mu \cdot K_{h}$ & $K_{h}$ & $\begin{array}{c}R_{p} \\
(\mathrm{kN})\end{array}$ & $\begin{array}{c}R=R_{p}+R_{f} \\
(\mathrm{kN})\end{array}$ & $R_{f} / R$ \\
\hline HS1D & $D_{r}=90 \%$ & 平板 & & 1.68 & 888 & 0.17 & 36.7 & 3.88 & 4.34 & 0.37 & 0.54 & $69 \%$ \\
\hline HS2L & & $t=0.2 \mathrm{~mm}$ & $100 \mathrm{~mm}$ & 0.92 & 520 & 0.09 & 17.5 & 1.99 & 2.65 & 0.18 & 0.27 & $67 \%$ \\
\hline HS3L & & & & 1.06 & 600 & 0.11 & 18.0 & 2.04 & 2.72 & 0.18 & 0.29 & $62 \%$ \\
\hline HS4L & & $t=02 \mathrm{~mm}$ & $50 \mathrm{~mm}$ & 1.34 & 759 & 0.067 & 17.7 & 2.00 & 2.67 & 0.044 & 0.11 & $40 \%$ \\
\hline HS5L & & & & 1.33 & 751 & 0.067 & 11.8 & 1.34 & 1.78 & 0.030 & 0.10 & $30 \%$ \\
\hline
\end{tabular}

補足 $1: R, R_{p}, R_{f}$ は $X=L$ での值

補足2: $\mu=(3 / 4) \tan \phi, \phi=50^{\circ}\left(D_{r}=90 \%\right)$ および $45^{\circ}\left(D_{r}=60 \%\right)$

\section{a） シートパイルの鉛直支持カのモデル化}

まず，シートパイル表面の水平土圧の上昇による周面 摩擦力の上昇を評価するため, 図-28 の貫入時の荷重変 位関係のモデル化を行う。貫入量 $X$ におけるシートパ イルの鉛直支持力 $R$ を，先端支持力 $R_{p}$ と周面摩擦力 $R_{f}$ に分離する. Dörr の支持力公式 40 にならい，先端支持力 が上載圧 $\sigma_{0}=\gamma X(\gamma$ : 単位体積重量) に比例し, 周面摩 擦力が水平土圧 $\sigma_{h}=K_{h} \sigma_{0}\left(K_{h}\right.$ : 水平土压係数）に対して クーロンの摩擦則が成り立つと仮定すると, 貫入量 $X$ で の先端支持力度 $q_{p}$ および深度 $x$ における周面摩擦力度 $r_{f}$ は，比例係数 $\lambda$ および摩擦係数 $\mu$ を用いて以下のように 表すことができる.

$$
\begin{aligned}
& q_{p}=\lambda \cdot \gamma \cdot X \\
& r_{f}=\mu \cdot \sigma_{h}=\mu \cdot K_{h} \cdot \gamma \cdot x
\end{aligned}
$$

シートパイル全体での先端支持力 $R_{p}$ は，先端支持力 度 $q_{p}$ に先端面積 $A_{p}$ を乗じて求めることができる. 一方, 全体での周面摩擦力 $R_{f}$ はシートパイルの幅 $w$ の裏表両 側で, 周面摩擦力度 $r_{f}$ を深度 $0 \sim X$ について積分して以 下のように求めることができる.

$$
\begin{aligned}
R_{f} & =2 \int_{0}^{X} r_{f} \cdot w \cdot d x \\
& =2 \mu \cdot K_{h} \cdot \gamma \cdot w \cdot \int_{0}^{X} x \cdot d x \\
& =\mu \cdot K_{h} \cdot \gamma \cdot w \cdot X^{2}
\end{aligned}
$$

以上より, 貫入量 $X$ における鉛直支持力 $R=R_{p}+R_{f}$ が, 以下の 2 次式でモデル化でき, 1 次項が先端支持力, 2 次項が周面摩擦力に分離される.

$$
\begin{aligned}
R & =\lambda \cdot \gamma \cdot A_{p} \cdot X+\mu \cdot K_{h} \cdot \gamma \cdot w \cdot X^{2} \\
& =\alpha_{1} \cdot X+\alpha_{2} \cdot X^{2}
\end{aligned}
$$

なお，図-28 中には，case-HS1D $\left(D_{r}=90 \%\right)$ および case-HS3L $\left(D_{r}=60 \%\right)$ について，それぞれ切片ゼロでの 近似 2 次曲線を点線で示しており, 上記の 2 次式でのモ デル化が妥当であることがわかる.

上記のモデル化に基づき，各ケースの貫入抵抗を評価 する. 図-28 中の全ケースの近似 2 次曲線（切片はゼ
口）の係数 $\alpha_{1}, \alpha_{2}$ と, 得られた係数から式(15)で逆算し た各ケースの所定の根入れ長さ $L$ での鉛直支持力 $R, R_{p}$, $R_{f}$ を表-4 に示寸. また, 表-4 中には, 各項の係数に対 して単位体積重量 $\gamma \quad\left(D_{r}=90 \%\right.$ で $\gamma=15.8 \mathrm{kN} / \mathrm{m}^{3}, D_{r}=60 \%$ で $\left.\gamma=1.47 \mathrm{kN} / \mathrm{m}^{3}\right)$ およびシートパイルの先端面積 $A_{p}$, 幅 $w$, 摩擦係数 $\mu$ から逆算した先端支持力の比例係数 $\lambda$ お よび水平土圧係数 $K_{h}$ を逆算した. ここで摩擦係数 $\mu$ は Dörr の支持力公式の下限側 $\mu=(3 / 4) \tan \phi$ とし ${ }^{40)} ， \phi$ は平面 ひずみ圧縮試験における内部摩擦角として， $D_{r}=90 \%$ で $\phi=50^{\circ}, D_{r}=60 \%$ で $\phi=45^{\circ}$ とした ${ }^{41), 42)}$.

逆算した水平土圧係数 $K_{h}$ は $1.8 \sim 4.3$ 程度と一般的な 静止土圧係数 $K_{0}=0.5$ 程度よりも大きくなっている. 模 型シートパイルは板厚 $t=0.2 \mathrm{~mm}$ と薄い模型ながら, 貫 入に伴い地盤を若干左右に押し広げたものと想定される が, 受㗢土圧係数 $K_{p}=\tan ^{2}\left(45^{\circ}+\phi / 2\right)\left(D_{r}=90 \%\right.$ で $K_{p}=$ $7.55, D_{r}=60 \%$ で $\left.K_{p}=5.83\right)$ までには至っていないこと から, 周面摩擦力が上昇する余地は十分残されていると いえる.

一方, 引抜き抵抗については, 水平土圧係数 $K_{h}$ を静 止土圧係数 $K_{0}=0.5$ として周面支持力を算出すると, $D_{r}=$ $60 \%$ で $R_{f}=-0.03 \mathrm{kN}$ 程度と押込み側支持力の $1 / 10$ 程度の 小さい值なる。これは実際の模型撤去時の引抜き抵抗が 非常に小さい值であったことと整合しており，模型撤去 時にはシートパイル表面の水平土圧は静止土圧程度か, それ以下まで低下したものと考えられる。

\section{b） シートパイル周辺の地盤変形状況}

シートパイル表面に作用する水平土圧の変化について 考察するため, シートパイル基礎の画像解析結果のうち, 最大変位時での地盤変位ベクトル図 (図-18 c) ) を元に, シートパイル周辺の地盤変位状況を整理する.

前面側（図中の右側）シートパイルの外側では，深さ 70〜80 mm程度まで一様に外向きの水平方向の地盤変位 が生じており, 明確な変位の不動点は見られず, 前面側 シートパイルは前面地盤を全体的に外側へ押していると 考えることができる. 一方, 前面側シートパイルの内側 の地盤では, 外側下向きの変位が生じている.また, 図-19 b) の底面反力ベクトルからは，地盤変位と同じ方 向に底面反力が発揮されていることがわかる．よって， 


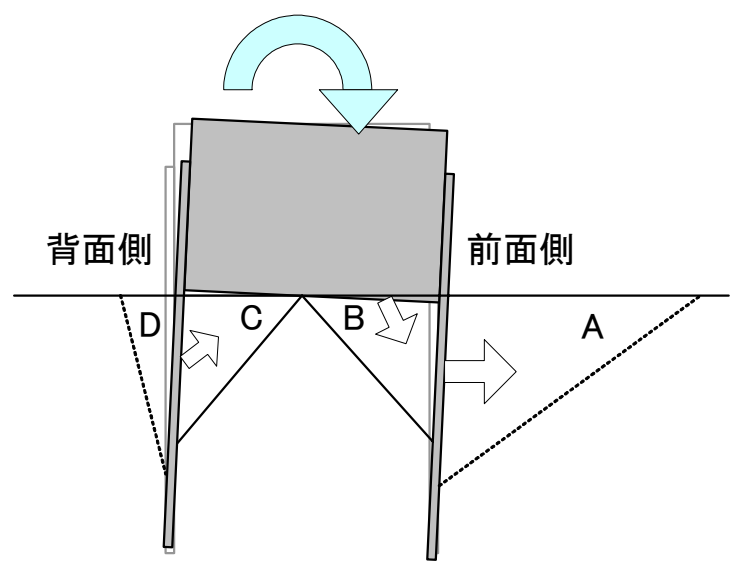

図-29 シートパイル周辺の地盤変位状況の模式図

フーチング底面がシートパイルの内側の地盤を押し，そ の地盤がシートパイルを内側から外側へ向かって押して いるものと考えられる.このことは，模型シートパイル の剛性 $(1 / \beta=37.7 \mathrm{~mm})$ に比べて比較的深い範囲まで地 盤変位が生じていることや，シートパイルの曲率計測結 果（図-20）でシートパイルが累積的に外側に開いてい く傾向が見られたことなどからも推定できる.

背面側 (図-18 c) 中の左側) シートパイル周辺をみる と，シートパイルの内側の地盤で，フーチング中心へ向 かう斜め上方向の変位ベクトルが生じており, 背面側シ 一トパイルが受働側に変位させたものと考えられる。一 方, シートパイルの外側では地盤変位がほとんど生じて おらず，シートパイルの近傍地盤は，空隙が生じるか， 非常に緩い状態になっていると考えられる.

以上のシートパイル周辺の地盤変位状況の模式困を 図-29に示す. シートパイル基礎の変形に伴い，フーチ ング底面の前面側は，内部地盤（図中B部）を押し，前 面側シートパイルを内側から押寸. 前面側シートパイル はフーチング経由で生じる頭部断面力のほかに，内部地 盤 (図中B部) からの土圧を受け，大きな曲率を生じる ことなく前面地盤（図中A部）を比較的一様に押して受 働状態となる. 一方，背面側シートパイルは，フーチン グに連動して移動するため, 背面側の内部地盤（図中C 部）を受働状態で変位させ，背面側の外側の地盤（図中 D部）を主働状態とする.

このような地盤変位状況下においては，シートパイル 表面の接触圧（水平土圧）が上昇するといら仮定は妥当 であると考えられ，前面側シートパイルの外側および背 面側シートパイルの内側は最大で受働土圧程度まで上昇 する可能性が十分に考えられる．また，このとき前面側 シートパイルの内側に作用する水平土圧も，内部地盤

(図中B部) にフーチング底面の鉛直反力が上載圧とし て作用するため比較的高い土圧となり，深い位置までシ 一トパイルが外側に変位していることから，内側の水平 土圧も外側と同程度まで上昇しているものと考えられる。

\section{c） 水平載荷時のシートパイルの鉛直支持力の推定}

シートパイルに作用する土圧がb)での考察に基づき受 働土圧になると仮定した場合の鉛直支持力をa)のモデル 化に基づいて推定する. ここでは，表-3のcase-HS3L（ $D_{r}$ $=60 \%, L=100 \mathrm{~mm})$ を対象とする.

前面側（押し込み側）シートパイルについては内外両 面とも受働土圧に達したと仮定 $\left(K_{h}=K_{p}=5.83\right)$ とすると， 鉛直支持力は $R=0.5 \mathrm{kN}$ まで増加する. 一方，背面側

（引抜き側）シートパイルでは，内面側のみ受働土圧に よる周面抵抗が発揮され，外面での周面抵抗は発揮され ないものと仮定すると, 引抜き抵抗力は $R_{f}=-0.2 \mathrm{kN}$ 程度 と, 水平土圧係数 $K_{h}$ を静止土圧係数 $K_{0}=0.5$ とした場合 の10倍近い值まで上昇する.

これらの水平載荷時の鉛直支持力の上昇を，表-3の水 平載荷時の発生軸力と比較すると，押し込夕側では発生 軸力を下回るものの，引抜き側では発生軸力と同程度の 值となっていることがわかる．表-3の発生軸力を底面反 力から逆算して求めていることによる評価精度の問題な どを考慮すると，これらは概ね一致していると判断でき る. よって，本節で示す水平載荷時の周面摩擦力が貫入 および撤去時よりも上昇するメカニズムは，妥当なもの であると考えられる．ただし，先端支持力の上昇の有無 や，水平土圧が実際に受働土圧まで上昇しているのか （特に前面側シートパイルの内側），シートパイル全長 にわたって上昇しているのかなど，不明な点も残されて おり，今後の検討課題といえる.

なお，極度に地盤が軟らかくシートパイルの剛性が極 端に高い場合には，前面側シートパイルの内面（図-29 中のBの領域）が主働状態となり，本節に示す周面摩擦 力向上メカニズムが十分に発揮されない可能性がある. しかしながら，本研究で対象とするシートパイル基礎は 仮土留め工の鋼矢板を本設利用することを前提としてい る. 仮土留め工の設計では土留め壁のたわみについて検 討を要する程度の比較的低剛性な鋼矢板を使用するのが 一般的であることから, 通常のシートパイル基礎ではこ のような問題は生じないと考えられる.

また，シートパイル先端のみが岩着する場合や，シー トパイルの根入れ長が非常に長くなる場合などでは, シ ートパイルの鉛直剛性が高くなるため，フーチング底面 での接地圧が低くなると考えられ，極度に地盤が軟らか い場合と同様に，本節に示寸ような周面摩擦力向上メカ ニズムが十分に発揮されない可能性がある。この場合, シートパイルの鉛直支持力には余裕があることとなるの で，改良効果は十分に発揮されると考えられるが，底面 反力による負担分を考慮すると過大評価となる可能性が あるので設計上は注意を要する. 


\section{5. 結論}

本研究では，主にシートパイル基礎のフーチング底面 と前背面シートパイルでの地盤抵抗に着目した2次元平 面ひずみ条件での模型水平交番載荷実験を実施し，シー トパイル基礎の地震時の水平抵抗特性の改良効果を確認 するとともに，シートパイル基礎の抵抗メカニズムにつ いて考察を行った. 特にその改良効果の定性的特徴と抵 抗メカニズムについて得られた知見を以下にまとめる.

\section{＜改良効果の定性的特徵＞}

a. 降伏震度, 降伏剛性，累積沈下量に対寸る改良効果 があり，回転中心深度が深くなる

b. シートパイルの根入れが長いほど, 改良効果が大き く，直接基礎の根入れと同程度の改良効果がある

c. シートパイル剛性の違いは主に初期岡性に影響し, 降伏以降の改良効果一の影響は小さい

d. 地盤が密なほど改良効果が大きい

\section{＜抵抗メカニズムに関する知見 $>$}

A. 底面地盤の外向きの水平変位がシートパイルにより 拘束され，累積沈下量が抑制される

B. 抵抗モーメントの大半は, シートパイルの鉛直支持 力による偶力モーメントであるが，フーチング底面 反力による回転モーメントも発揮されている

C. 水平載荷時はシートパイルの鉛直支持力（特に周面 摩擦力）が貫入時よりも上昇し, 高い偶力モーメン トが発揮される

D. シートパイルの曲げ抵抗の負担は小さい

なお，シートパイル基礎の改良効果を十分に発揮する ためには，特に上記BおよびCの抵抗メカニズムを発揮 させる必要があり, そのためには以下の条件が必要とな る.

1. シートパイルの曲げ剛性を底面地盤の剛性に比べて 極度に硬くしないこと（仮土留めとして設計する）

2. シートパイルの先端を極度に硬い支持層に定着させ ないこと（完全支持杭としないこと）

上記の2条件は本研究で想定するシートパイル基礎の 開発コンセプト「直接基礎と杭基礎の中間程度の地盤条 件において直接基礎と仮土留め工用の鋼矢板と組み合わ せた基礎形式」の範囲において, 新設設計段階であれば いずれも容易に満足できる条件である。ただし，既設基 礎の補強工法としてシートパイル基礎を適用する場合に は，特に2.の条件を満足しない（先端支持させる）こと
も多い，そのような場合には，フーチング底面での反力 を期待しない設計とするなどの配慮が必要であろう。こ のほか，極度に地盤が軟らかい場合なども本研究で得ら れた知見の対象外となる. 実務設計上の適用に際しては, 例えば比較的水平力の小さい常時についてはシートパイ ルを無視した通常の直接基礎として設計するなど安全側 の配慮が必要と考えられる.

\section{6. おわりに}

本研究により，シートパイル基礎の基本的な水平抵抗 特性および抵抗メカニズムを把握することができた。本 研究では，2次元模型による実験により基礎的な検討を 行ったが, 実構造物では3次元的な補強効果, 特に載荷 方向に対して側面に配置されるシートパイルのせん断抵 抗により，さらに高い改良効果が発揮されるものと想定 される.これらの影響については，3次元模型による振 動実験を実施し, 別報 3 にてて報告しているので，これを 参照されたい.

\section{参考文献}

1) 鉄道総合技術研究所編：鉄道構造物等設計標準・同解説 （SI単位版）基礎構造物・抗土圧構造物，丸善，2000.6

2) 地盤工学会編: 新編 土と基礎の設計計算演習, pp.47-49, 2000.11

3) Meyerhof, G. G. : The ultimate bearng capacity of foundations, Géotechnique, Vol.2, No.4. pp.301-334, 1951.

4) Meyerhof, G. G. : The bearing capacity of foundations under eccentric and inclined loads, Proc. 3rd Int. Conf. Soil Mech. \& Found. Eng., Vol.1, pp.440-445, 1953.

5) 例えば, 土木学会 : コンクリート標準示方書・耐震設計編 [平成8年制定］，1996.7

6) 羽矢洋，西村昭彦 : 大地震力を考慮した直接基礎の設計法 の提案，土木学会論文集，No.595/VI-39，pp.127-140，1998.6

7) 鉄道総合技術研究所編 : 鉄道構造物等設計標準 - 同解説 而振設計，丸善， 1999.10

8) 東日本旅客鉄道株式会社 : 新潟県中越地震復旧記録誌, pp.135, 2005.10

9) 東日本旅客鉄道株式会社構造技術センター: 特集「新潟県 中越地震と鉄道」，SED，第24号，pp.36，2005.8

10) 仁杉嚴, 久保村圭助, 町田冨士夫 : 巨大地震と高速鉄道 新潟県中越地震をふりかえって, pp.219, 山海堂, 2006.11

11) 浅井隆一, 白戸真大, 福井次郎, 野々村佳哲 : 直接基礎の 地震時残留変位に関する繰返し載荷実験, 第49回地盤工学 シンポジウム平成16年度論文集，pp.379-386，2004.12

12) 宮浦征宏, 三浦清一, 川村志麻, 横浜勝司 : 載荷条件の相 
違による砂地盤の支持力一変形挙動の変化とその評価, 土 木学会論文集，No.673/III-54，pp.121-131，2001.3

13) Nova, R. and Montrasi, L. : Settlements of shallow foundations on sand, Géotechnique, Vol.41, №.2, pp.243-256, 1991.

14) Butterfield, R. and Gottardi, G. : A complete three-dimensional failure envelope for shallow footings on sand, Géotechnique, Vol.44, No.1, pp.181-184, 1994.

15) Okamura, M. and Matsuo, O. : A displacement prediction method for retaining walls under seismic loading, Soils and Foundations, Vol.42, No.1,pp. 131-138, 2002.2

16) 梅原俊夫，福島弘文 : 緩い砂地盤に高架橋ができるまで— 国鉄釧網線網走高架橋一，土と基礎，Vol.34，No.9，pp.33$38,1986.9$

17) 古山章一, 瀧内義男 : 直接基礎を緩い砂礫地盤八適用寸る 場合の検討方法，土木学会論文集，No.623 / VI-43，pp.45-55, 1999.6

18)日本建築学会 : 建築基礎構造設計指針2001年版, pp.339-348, 2001.10

19) 神田政幸, 村田修, 西岡英俊, Pongsakom Punrattanasin, 日下部 治 : シートパイルとフーチングを組み合わせたシートパイ ル基礎の提案，土と基礎，Vol.51，No.11，pp.8-10，2003.11

20) 喜多直之, 田中浩一, 平尾淳一, 神田政幸, 西岡英俊 : シ ートパイルとフーチングの接合構造に関する実験と設計法, 土木学会第60回年次学術講演会概要集, 6-246, 2005.9

21) 西岡英俊, 神田政幸, 舘山勝, 村田修, 平尾淳一, 樋口俊一: 静 的模型実験による鋼矢板併用直接基礎の鉛直支持力特性に 関する研究，土木学会論文集C，Vol.63，No.4，pp.285-298， 2007.

22) 西岡英俊, 神田政幸, 村田修, 松田隆, 平尾淳一: シー卜 パイル基礎の接合方法に関する模型実験, 第49回地盤工学 シンポジウム平成16年度論文集，pp.275-282，2004.12

23) 渡辺健治, 舘山勝 : 画像解析システムを用いた模型擁壁実 験に関する考察，鉄道総研報告，Vol.17，No.3，pp.19-24， 2003.

24) 谷和夫, 龍岡文夫 : 砂地盤上の帯基礎の底面の摩擦角分布 測定に用いるロードセルの試作とその特性について，土木 学会第40回年次学術講演会講演概要集, pp.775-776, 1985.

25) 鋼管杭協会 鋼矢板技術委員会 : 鋼矢板 設計から施工ま で，鋼管杭協会，p.467，2000.

26 鉄道総合技術研究所編 : 鉄道構造物等設計標準・同解説 開削トンネル 付属資料・掘削土留め工の手引き, pp.217, 丸善, 2001.3

27) 日本道路協会編 : 道路土工 仮設構造物工指針, pp.107, 丸善, 1999.3

28) 例えば, 渡邊忠朋, 谷村幸裕, 瀧口将志，佐藤勉 : 鉄筋コ ンクリート部材の損傷状況を考慮した変形性能算定手法, 土木学会論文集，No.683/V-52，2001.8
29) 大槙正紀, 西村右敏 : 偏心傾斜荷重を受ける粘性土地盤の 模型実験と解析, 第35回土質工学シンポジウム論文集, IV2, pp.93-100, 土質工学会, 1990.11

30) Dean, E. T. R., James, R. G., Schofield, A. N. and Tsukamoto, Y. : Theoretical modelling of spudcan beheviour under combined load, Soils and Foundations, Vol.37, No.2, pp.1-15, 1997.

31) Punrattanasin, P., Nishioka, H., Murata, O. and Kusakabe, O. : Development of combined loading apparatus for centrifuge test, International Journal of Physical Modeling in Geotechnics, Vol.4, pp.1$13,2003$.

32) 神田政幸, 西岡英俊, 山畑栄, 高橋一人, 甲斐輝雅 : 鉛直 力・水平力・モーメントおよび鉛直変位・水平変位・回転 角による載荷制御可能な基礎構造物の載荷試験装置の開発, 第40回地盤工学研究発表会平成17年度発表講演集, pp.14611462, 2005.7

33）土質工学会基準 : 杭の水平載荷試験方法 - 同解説, pp.28, 1983.

34) 鉄道総合技術研究所編 : 鉄道構造物等設計標準・同解説 而震設計 設計計算例 鉄筋コンクリート橋脚（直接基 礎），鉄道総合技術研究所，2000.

35) 西岡英俊, 神田政幸, 村田修, 伊藤政人, 田中浩一 : シー トパイル基礎の水平抵抗特性に関する静的模型実験, 土木 学会第58回年次学術講演会講演概要集, pp.501-502, 2003.9

36) 西岡英俊, 神田政幸, 村田修, 田中浩一, 樋口俊一 : 緩い 砂地盤上のシートパイル基礎模型の水平載荷実験, 第39回 地盤工学研究発表会平成16年度発表講演集, pp.1421-1422, 2004.7

37) 西岡英俊, 田中浩一, 神田政幸, 樋口俊一, 村田修, 松田 隆 : 模型実験によるシートパイル基礎の支持力および而震 性能の検討，土と基礎，Vol.53，No.4，pp.24-26，2005.4

38) 妙中真治, 大谷順, 佐藤宇紘 : 鋼矢板の鉛直支持力特性の 評価, 土木学会論文集C，Vol.63，No.1，pp.285-298， 2007.

39) 坂田隆搏, 前田良刀, 落合英俊, 安福規之, 横田康行 : 傾 斜荷重を受ける柱状基礎の水平方向塑性地盤反力, 土木学 会論文集，No.610/III-45，pp.69-82，1998.

40) 土木学会編, 大橋勝弘・矢作枢編著 : 新体系土木工学 45 基礎工（I），pp.124-126，技報堂出版， 1980 .

41)地盤工学会編 : 入門シリーズ13 土の強さと地盤の破壊入門, pp.65, 地盤工学会, 1987.

42) Tatsuoka, F., Sakamoto, M., Kawamura, T. and Fukushima, S. :Strength and deformation characteristics of sand in plane strain compression at extermely low pressures, Soils and Foundations, Vol.26, No.1, pp.65-84, 1986.

43) 樋口俊一, 田中浩一, 神田政幸, 西岡英俊 : シートパイル 基礎の耐震性能に関する実験的研究，土木学会論文集A, (投稿中) 


\title{
A STUDY FOR CHARACTERISTIC OF LATERAL RESISTANCE OF FOOTING FOUNDATION WITH SHEET PILES BY STATIC LOADING TEST
}

\author{
Hidetoshi NISHIOKA, Masayuki KODA, Masaru TATEYAMA, \\ Naoyuki KITA, Junichi HIRAO and Shunichi HIGUCHI
}

Authors proposed a sheet-pile foundation that combined sheet piles with footing. Sheet-pile foundation can be expected the reinforcement effect of constraint of the ground. Because sheet piles reinforce the inside ground of sheet piles, the sheet-pile foundation has higher seismic resistance than footing foundation.

In this research, a series of lateral static loading tests of sheet-pile foundation and footing foundation were conducted. The pressures of the bottom of the footing were measured, and the ground displacement was calculated by image processing system. It was found from these results that sheet-pile foundation had the improved effect of seismic resistance and settlement, and that the improved effect was demonstrated by vertical resistance of sheet piles. 